\title{
Rekrutteringen til de utøvende musikkutdanningene i Norge
}

En analyse av søkermassen ved opptaket til de utøvende musikkutdanningene i Norge, med fokus på endringer over tid i forholdet mellom de klassiske og de rytmiske søkergruppene

Knut Tønsberg

Keywords

Recruitment, popular music education, classical music education

\begin{abstract}
The admission to the music performance programs in Norway is not coordinated. There are good reasons for that, but it also presents some challenges. An example of these is that there are no surveys at the national level of the changes over time in the number of applicants to the classical and popular music performance programs. The article contributes to new knowledge and insight in this area in that it explains and discusses the findings of three empirical studies in the 2000s, studies that provide the basis for answering the question: Is it in Norway today more applicants to the popular music educations than to the classical ones?
\end{abstract}

\section{Innhold}

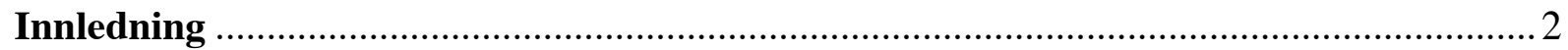

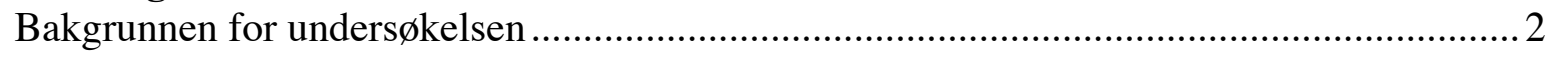

Populasjonen - den totale, nasjonale søkermassen på individnivå ....................................5

Empirien - søkerne fordelt på sjanger, profil, kjønn og instrument ................................. 7

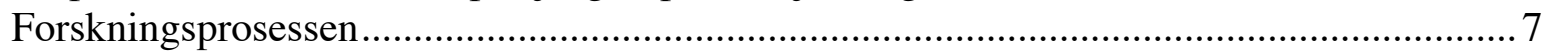

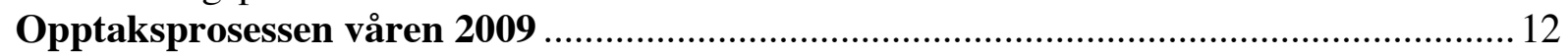

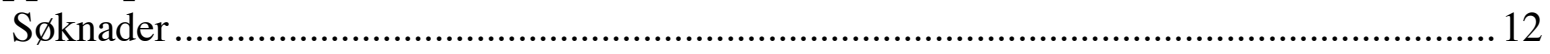

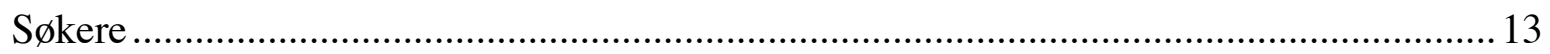

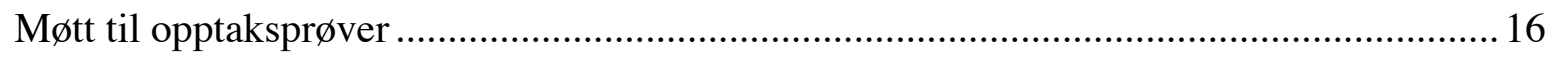

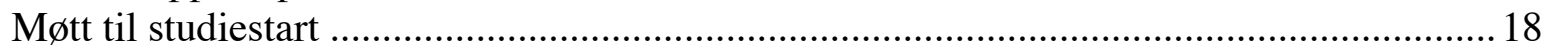

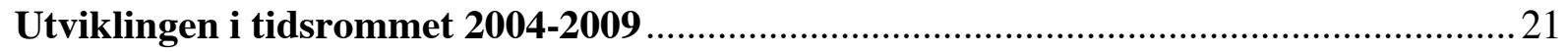

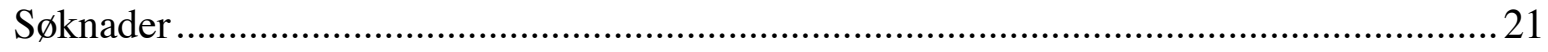

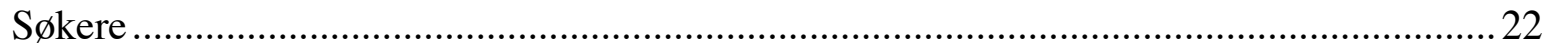

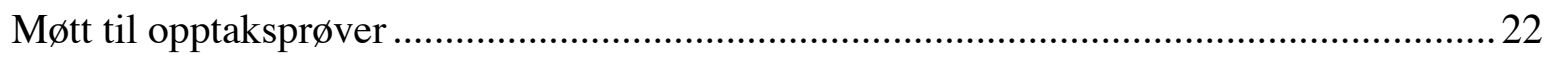

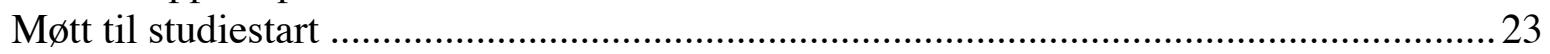

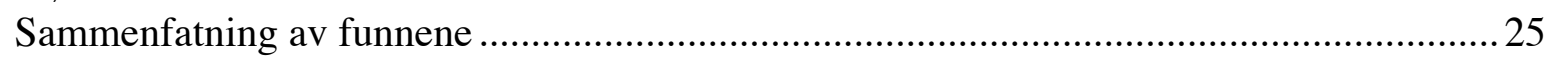

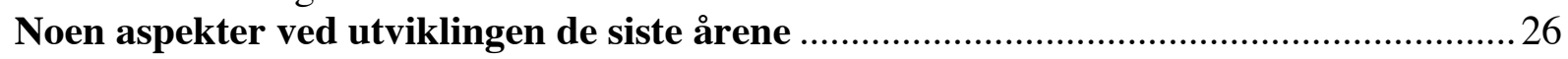

Er det flere jazz-rytmiske enn klassiske søkere i Norge i dag? ........................................26

Hvordan er utviklingen når det gjelder søkningen til pedagogiske studieforløp? ...............26

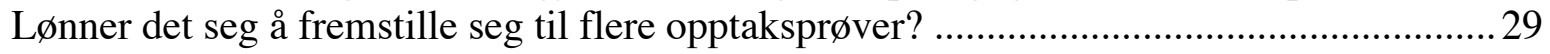

Hvorfor $\emptyset$ ker andelen av menn innen de ut $\varnothing$ vende utdanningene? ..................................... 30

På hvilke instrumenter har man størst sjanse for å få studieplass? ...................................... 31

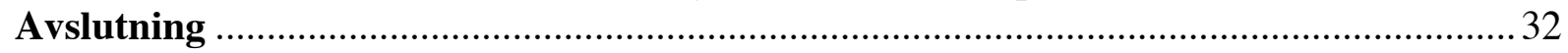

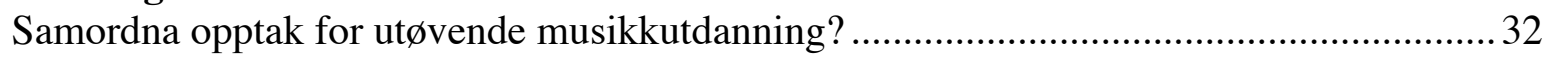

Tilbud og etterspørsel og musikkutdanningsinstitusjonenes samfunnsoppdrag ................. 34

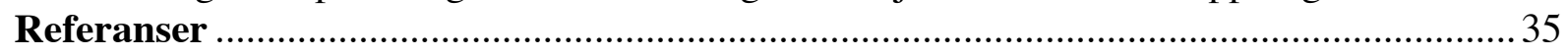

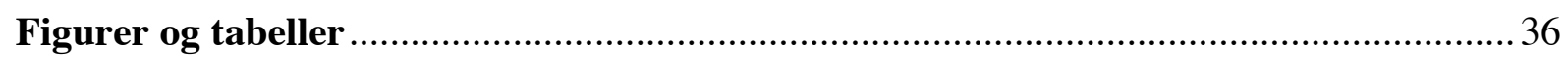




\section{Innledning}

Er det i Norge i dag flere søkere til de jazz-rytmiske musikkutdanningene enn til de klassiske? Hvor mange møter fram til opptaksprøvene i de to søkergruppene? Hvor stort er frafallet? Hvordan er forholdet mellom søkning og antall tilbudte klassiske og jazz-rytmiske studieplasser? På hvilke instrumenter er det størst sjanse for å komme i betraktning for en studieplass? Lønner det seg å møte fram til opptaksprøver ved flere institusjoner? Spørsmål som dette er lette å formulere, men vanskelige å besvare på nasjonalt nivå, av grunner som det blir gjort rede for nedenfor. Formålet med artikkelen er å formidle ny kunnskap om nasjonale endringer over tid i rekrutteringen til de utøvende musikkutdanningene i Norge og drøfte årsaker og konsekvenser når det gjelder ovennevnte og beslektede spørsmål. Grunnlaget for funnene er undersøkelser av søkermassen ved opptaket til de utøvende musikkutdanningene i Norge i årene 2004, 2006 og 2009, der fokuset var særlig på endringer over tid i forholdet mellom de klassiske og de jazz-rytmiske søkergruppene. I det følgende vil jeg begrunne nødvendigheten av unders $\varnothing$ kelsen og gjøre rede for gjennomføringen av den.

\section{Bakgrunnen for undersøkelsen}

Den viktigste grunnen til at spørsmålene ovenfor er vanskelige å besvare, er at søkningen til de utøvende musikkutdanningene i Norge (tidligere konservatoriesektoren) ikke er omfattet av "Samordna opptak" (SO), et departementalt initiert serviceorgan som ble etablert på 1990tallet. Dette organet koordinerer i dag opptaket til de fleste universiteter og høgskoler i Norge. Begrunnelsene for etableringen var utstrakt parallellsøkning (gjennomsnittlig åtte søknader per søker i 1993), stor ressursbruk i søknadsbehandlingen på grunn av mye dobbeltarbeid, stort frafall av søkere gjennom hele søknadsprosessen, tilfeldig tildeling av studieplasser og manglende oversikt over søkertallene for hvert år og søkemønsteret over tid, noe som førte til dårlig dimensjonering av opptakskapasiteten og umuliggjorde langsiktig strategisk planlegging (Skjersli 2000, Brandt et al. 2005).

I dag publiserer SO fortløpende statistikk på nasjonalt nivå om søkning, tilbud og opptak til høyere utdanning, og organet kan svare på spørsmål av den typen som er nevnt innledningsvis, men altså ikke for de utøvende musikkutdanningene. Det var som et ledd i mitt doktorgradsprosjekt om institusjonaliseringen av de rytmiske musikkutdanningene ved Universitetet i Agder (Tønsberg 2007) at undersøkelsen ble gjennomført; i årene 2004, 2005 og 2006. Omfattet av undersøkelsen var de seks tidligere rent klassiske musikkonservatoriene, som i løpet av et tidsrom på 25 år, fra 1979 til 2004, etablerte jazz-rytmiske 
musikkutdanninger som supplement til de klassiske utdanningene: Norges musikkhøgskole i Oslo (NMH), Universitetet i Agder (UiA), Universitetet i Stavanger (UiS), Universitetet i Bergen (UiB), Norges teknisk-naturvitenskapelige universitet i Trondheim (NTNU) og Universitetet i Tromsø (UiT). Senere ble det også samlet inn søkerdata fra 2009, og opptaksåret 2005 er blitt utelatt fra fremstillingen på grunn av ufullstendige data, slik at det er de innsamlede dataene fra opptaksårene 2004, 2006 og 2009 som danner basis for analyse og drøfting.

Nå finnes det et samordningsorgan for de utøvende musikkutdanningene i Norge, nemlig Nasjonalt fagråd for musikk. Dette organet, som er organisert under Universitets- og høgskolerådet, publiserer en fellesbrosjyre som regulerer og koordinerer opptaket til de utøvende institusjonene. I denne brosjyren går det fram at opptaksprøvene ved UiA, UiS, UiB, UiT og de klassiske utdanningene ved NTNU finner sted i samme uke, mens NMH og jazzutdanningen ved NTNU har egne opptaksuker. Det som også gikk klart fram av brosjyren, og som gjaldt fram til opptaksprøvene i 2011, var at man ikke kunne søke til mer enn én av de institusjonene som har felles opptaksuke. Til tross for dette "forbudet", som altså nå er fjernet fra fellesbrosjyren, er det en kjent sak innenfor de utøvende musikkutdanningene at en del søkere allikevel har sendt søknadsskjemaer og møtt fram til opptaksprøver ved flere av disse institusjonene, fordi de har antatt at dette ville $\varnothing$ ke sjansene for å komme i betraktning. Og dette er en praksis som har eksistert i mange år. Fra min undersøkelse finnes eksempler på søkere som har sendt søknadsskjema til samtlige seks institusjoner. Når en og samme person dermed kunne gå igjen i alle søkerlistene, hvor stor har da egentlig den nasjonale søkningen til de utøvende musikkutdanningene vært? Og hva med den store søkningen til jazz-rytmiske utdanninger som det meldes om fra enkelte hold (KUF 1999 § 8.4)? Er den faktisk høyere enn søkningen til klassiske utdanninger, eller bare virker det slik fordi de jazz-rytmiske søkerne kanskje produserer flere søknader enn de klassiske?

Oversikter over søkerne til hver enkelt institusjon sendes til "Norsk samfunnsvitenskapelig datatjeneste" (NSD), som legger dataene inn i "Database for statistikk om høgre utdanning" (DBH). DBH baserer altså statistikken på innsendte rapporter fra institusjonene over antall søkere til den enkelte institusjon. Tabellene som man finner i disse basene, gjengir tallmaterialet fra de enkelte institusjonene, men de tar ikke høyde for dem som søker flere institusjoner, og som derfor figurerer i flere tabeller. Hvis man ønsker søkerstatistikk på nasjonalt nivå, er disse databasene ubrukelige. Én søker med seks søknader blir til seks søkere i rapporteringen, hvilket betyr at DBH kun har opplysninger om antall søknader; ikke antall søkere. Ved starten på datainnsamlingen opererte DBH med betegnelsen 
"hoder" i forklaringen til tabeller som inneholdt tall på søknader. Dette var misvisende, og er da også blitt endret de siste årene. Fremdeles er det imidlertid begrepet "søkere" som er brukt på forsiden av DBHs offisielle nettside, selv om man stadig, ved summering av tallene inne i tabellen, kun får brutto antall søknader. Ifølge disse tabellene for 2009 er summen av antall søknader til de utøvende musikkutdanningene i Norge 2058; men hvor mange søkere skjuler det seg bak dette tallet?

Denne typen spørsmål burde blitt stilt av det utvalget som ble oppnevnt i 1998 av Kirke-, utdannings- og forskningsdepartementet for å utrede den faglige organiseringen av musikkutdanningen i Norge. Utredningen Fra vugge til podium (nedenfor kalt Boysenrapporten) (KUF 1999) hevdet at praksisen med å sende søknader til flere eller samtlige institusjoner ikke forekom:

Det kan være en viss dobbeltsøkning mellom NMH og konservatoriene, men ikke mellom konservatoriene, som har samordnet opptaket (KUF 1999 § 4.5.4).

Siden utvalget ikke tok høyde for slik mangedobbel søkning, har oversiktene over søkerne i Boysenrapporten begrenset verdi. Derimot lar rapporten seg bruke som bakgrunnsmateriale for frammфtte til studiestart. Her hersker det aldri tvil om antallet; én person kan aldri være student ved flere enn én institusjon.

For å komme et stykke lenger enn disse kildene, som bare opererte med ikkesummerbare, brutto søkertall, måtte min undersøkelse dreie seg om data på individnivå. Jeg måtte samle inn direkte identifiserende personopplysninger om samtlige personer som søkte de utøvende musikkutdanningene i ett og samme år. Først med en slik fullstendig oversikt var det mulig å kunne si noe om den egentlige etterspørselen etter studieplasser på dette feltet i Norge.

Når det gjelder spesifikke opplysninger om klassiske, henholdsvis jazz-rytmiske søknadstall, har oversiktene fra DBH slike data kun for to av institusjonene, fordi disse to rapporterer sjangerspesifikke tall. Ved de andre fire institusjonene er tallene slått sammen, og det opereres med betegnelser som musikk, utøvende musikk eller musikkutøving. Dermed er DBH ubrukelig også som kilde til mitt viktigste anliggende i undersøkelsen, nemlig utviklingen de siste årene $\mathrm{i}$ forholdet mellom rekrutteringen og opptaket til henholdsvis klassiske og jazz-rytmiske grunnutdanninger.

I tillegg til at parallellsøkning innenfor de utøvende musikkutdanningene er et kjent, men ikke kartlagt fenomen, har vi å gjøre med et stort frafall i løpet av søknadsprosessen. Det er særlig problematisk med de søkerne som ikke møter fram til opptaksprøvene. Noen av 
disse har gitt melding på forhånd, mens andre uteblir uten å gi beskjed. En rekke aspekter ved frafall i søknadsprosessene er analysert av "Norsk institutt for studier av innovasjon, forskning og utdanning" (NIFU STEP), og funnene herfra blir brukt som utgangspunkt for en drøfting av mine egne funn. Frafallet blir gjerne kategorisert i tre faser: 1) "tidlig frafall" (de som trekker seg tidlig i prosessen), 2) "nei til studietilbud" (de som får tilbud, men takker nei til studieplass) og 3) "ikke møtt" (de som tar imot en studieplass, men som ikke møter ved studiestart) (Brandt et al. 2005:20). Ved opptaket til utdanninger med opptaksprøver kommer det inn enda en kategori etter den første: "ikke møtt til opptaksprøver”. I undersøkelsen av opptaksprosessen i dette utdanningsfeltet er denne kategorien en av de viktigste å få belyst.

Opplysningene som er samlet inn, er direkte personidentifiserende. NSD, som også fungerer som "Personvernombudet for forskning", har uttalt seg om nødvendigheten av undersøkelsen og gitt dispensasjon fra de paragrafene i lov om behandling av personopplysninger (Lovdata 2001) som ellers ville ha stoppet datainnsamlingen. Ifølge Personvernombudet hadde undersøkelsen "allmenn interesse innenfor universitets- og høgskolesektoren" og særlig for konservatoriesektoren, sett ut fra et "institusjonspolitisk, strategisk og økonomisk perspektiv". Videre ble det hevdet å være en "stor interesse for institusjonene ut fra planleggingshensyn, å vite noe om hvor stor etterspørselen blant musikere egentlig er når det gjelder høyere instrumentalutdanning, og hvordan etterspørselen fordeler seg i forhold til klassisk og rytmisk instrumentalutdanning”. I hovedavsnittet nedenfor om forskningsprosessen gjøres det rede både for prosedyrene for datainnsamlingen og de forskningsetiske dilemmaene som oppsto ved innhentingen og behandlingen av personopplysningene.

I tillegg til Boysenrapporten og de norske forskningsrapportene som allerede er nevnt, som alle omhandler aspekter ved rekrutteringen til høyere musikkutdanning, refererer jeg til den svenske studien om rekrutteringen til blant annet musikklærerutdanning i Sverige (Brändström et al. 1995), rapporten fra den nasjonale evalueringen av høyere musikkutdanning (KUF 1996) og undersøkelsen fra 1999 om yrkeslivet til norske rytmiske musikere og musikkpedagoger etter endt utdanning (Tønsberg 2000).

\section{Populasjonen - den totale, nasjonale søkermassen på individnivå}

Fellesbrosjyren, som er nevnt ovenfor, omfatter åtte musikkutdanningsinstitusjoner, hvorav altså seks inngår i undersøkelsen. De to institusjonene som ikke er med, er Barratt Due musikkinstitutt og Operautdanningen ved Kunsthøgskolen, begge beliggende i Oslo. Disse har imidlertid valgt å opprettholde en rent klassisk-musikalsk profil og egner seg ikke i en 
undersøkelse av aspekter ved rekrutteringen til jazz-rytmisk og klassisk musikkutdanning. Populasjonen er samtlige søkere til grunnutdanningene ved de seks institusjonene. Det empiriske materialet er altså ikke et utvalg; det er selve den teoretiske populasjonen (Jacobsen 2003:159) av søkere til den norske musikkonservatoriesektoren, i årene 2004, 2006 og 2009, som er gjenstand for analyse. Disse tre fullstendige populasjonene inneholder et bestemt antall fysiske personer, og disse personene er registrert i databaser ved den enkelte institusjon med navn, instrument og førsteprioritets studieønske, samt en rekke andre opplysninger. Det er rapporter fra disse institusjonelle databasene som jeg har fått tilsendt, og har behandlet og analysert.

Jeg bruker uttrykkene klassisk og jazz-rytmisk, både om søknader, søkere, opptaksprøver, studenter og utdanninger. Jeg går ikke her inn i en diskusjon om forholdet mellom jazz og rytmiske sjangere, om hvilke sjangere som omfattes av samlebegrepet rytmisk musikk, eller om jazz hører med til rytmisk musikk. Det som er poenget i denne sammenhengen, er at to av de seks nevnte institusjonene, UiA og UiT, har en større sjangerbredde i sitt studietilbud og bruker begrepet "rytmisk" i sammenhenger som rytmisk musikk, rytmisk sjanger og rytmisk hovedinstrument, mens de andre fire opererer med begrepene "jazz" eller "improvisert musikk/jazz" og altså sjangermessig sett har et mer spisset studietilbud. Også DBH opererer med begge termene jazz og rytmisk i sine tabeller. Når jeg benytter sammenstillingen jazz-rytmisk, er det fordi ingen av begrepene alene har et bredt nok meningsinnhold til å kunne fungere som fellesbetegnelse for den ikke-klassiske delen av empirien, enten det dreier seg om søkerne, sjangerne, studiene eller instrumentene. I enkelte av tabellene og figurene har jeg allikevel, av plasshensyn, brukt forkortelsene "jazz" og "klass.".

Det finnes en rekke ulike grunnutdanninger ved de utøvende musikkinstitusjonene i Norge. Jeg har valgt å konsentrere meg om utøvende musikerutdanninger og faglærerutdanninger, altså musikkfaglige, opptaksbaserte bachelorutdanninger, med eller uten pedagogisk komponent, og med hovedinstrumentrelaterte emner som vesentlige komponenter. Disse utdanningene har et omfang på tre eller fire år. Tre musikkinstitusjoner tilbyr i dag pedagogisk komponent kun som en valgfri praktisk-pedagogisk utdanning, etter to eller tre år med utøvende studier. Ved de tre andre institusjonene tas studentene opp til enten et rent utøvende eller et pedagogisk-utøvende studieforløp. Det finnes også grunnutdanninger med basis i folkemusikk/tradisjonsmusikk, orgel/kirkemusikk, komposisjon og frie studier. I vid forstand kunne søkerne også til disse studiene gjerne blitt kategorisert som enten klassiske eller jazz-rytmiske, men jeg har valgt å utelukke disse fra undersøkelsen, også fordi søkningen 
til dem er relativt lav. Mitt anliggende er de to største gruppene av søkere, nemlig de klassiske og de jazz-rytmiske.

\section{Empirien - søkerne fordelt på sjanger, profil, kjønn og instrument}

De aspektene jeg fokuserer på, er søkermengden til jazz-rytmiske grunnutdanninger sammenlignet med søkningen til klassiske grunnutdanninger (sjanger), forholdet mellom søkningen til pedagogiske og utøvende studier (profil), kjønn og instrument. Aspekter jeg ikke fokuserer på, er blant annet hvor søkerne kommer fra i landet, søkernes alder, om søkerne tilhører minoritetsgrupper, og antall kvalifiserte etter opptaksprøvene. Hvorfor fokuserer jeg ikke på antall kvalifiserte? Fordi prosedyrene for vurdering av kvalifisert / ikke kvalifisert eller godkjent / ikke godkjent varierer svært mye fra institusjon til institusjon. For det første blir det andre og dermed usammenlignbare krav til godkjent spill ved en institusjon med få søkere enn ved en institusjon med mange søkere. For det andre blir kanskje bare de 20 beste på et instrument med 70 søkere definert som kvalifiserte og rangert i forhold til hverandre, mens de resterende 50 ikke blir det; selv om også disse hadde bestått opptaksprøven; mest for at juryen skulle slippe å rangere 70 prestasjoner, når det allikevel bare kunne tas opp tre nye studenter. Jeg tar heller ikke opp temaer som økonomi, ledelse og lærere; ei heller opptakskapasitet, måltall og andre aspekter ved den enkelte institusjon. Jeg fokuserer i fortsettelsen ikke på enkeltinstitusjoner, men fastholder det overordnede, nasjonale perspektivet.

I det følgende gjøres det først rede for forskningsprosessen. Deretter går jeg i detalj gjennom funnene fra opptaksåret 2009, strukturert etter de fire nivåene eller fasene søknader,

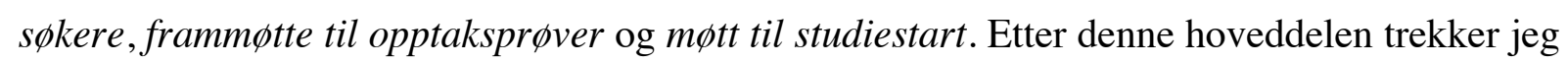
linjene bakover til 2006 og 2004, og peker på mulige utviklingstrekk over et tidsrom på seks år, for til slutt å antyde noen mulige fremtidige konsekvenser av disse tendensene.

\section{Forskningsprosessen}

Nedenfor gjør jeg rede for fremgangsmåten for innsamling av søkerdataene, jeg vurderer dataenes pålitelighet og funnenes gyldighet, og jeg berører personvernproblematikk. For at samme type undersøkelse skal kunne gjentas med en høy grad av intersubjektivitet og etterprøvbarhet, er prosedyreredegjørelsen relativt detaljert.

\section{Datainnsamlingen}

Søkerlistene ble innhentet i løpet av januar og februar i det aktuelle året (søknadsfrist har vært 15. desember i hele tidsrommet 2004-2009), enten i form av papirkopier sendt i posten eller 
som Word- eller Excel-filer som vedlegg til e-post. Enhetene og verdiene ble registrert av meg selv i statistikkprogrammet SPSS (Statistical package for social sciences), enten manuelt fra papirkopiene eller ved bearbeiding og kopiering fra Word og Excel. Det ble opprettet to filer; én for dataene for 2004 og 2006 og én for dataene fra 2009. Da selve registreringen av dataene var gjort, alfabetiserte jeg enhetene etter etternavn, slik at alle dublettene kom til syne. Sorteringsverktøyet avslørte hvem som hadde produsert én, to, tre, fire, fem eller seks søknader; sistnevnte enkeltindivider la beslag på seks rader under hverandre i databasen. Etter å ha flyttet alle verdiene for én og samme søker opp på én og samme rad, og deretter fjernet de tomme dublettradene, sto jeg igjen med en database der én rad inneholdt samtlige opplysninger om én person, og der kolonnene utgjorde variablene, hvorav de viktigste var etternavn, fornavn, instrument, kjønn, klass./jazz, utøvende/pedagogisk, søkte institusjoner, søkte studier og søkte år. Etter hvert som opptaksprosessen ble avviklet utover våren, ble opplysninger om møtt eller ikke møtt til opptaksprøver (prøvene ble normalt gjennomført i mars måned) innhentet fra institusjonene. Til slutt registrerte jeg eventuell status som førsteårsstudent, noe som fremgikk av innhentede klasselister påfølgende høst. Analyseverktøyene i programmet ble brukt for å få fram beskrivende statistikk i form av absolutte og relative fordelinger, ved å foreta rene frekvensberegninger og ved kombinasjon av variabler. Siden dette ikke er en utvalgs-, men en populasjonsundersøkelse, er det ikke så relevant å gjennomføre tradisjonell statistisk analyse; forskjellen i størrelse mellom for eksempel en gruppe klassiske og en gruppe jazz-rytmiske søkere lar seg avlese direkte av de absolutte tallene. Om slike forskjeller, for eksempel når det gjelder endringer over tid ved studiestart, i "styrkeforholdet" mellom klassisk og jazz-rytmisk, kan tolkes som små eller store, kommer an på hva som forventes. Forventer man ingen forskjell, kan selv en liten forskjell være interessant (Jacobsen 2000:322). Slike vurderinger og tolkninger foretas og begrunnes etter hvert som resultatene fremstilles i teksten.

\section{Vurdering av søkertallenes pålitelighet og funnenes gyldighet}

Nedenfor gjennomgås noen aspekter som har å gjøre med søkertallenes pålitelighet og funnenes gyldighet. Dette dreier seg om i hvilken grad jeg kunne stole på dataene i de søkerlistene som jeg fikk tilsendt fra institusjonene, risikoen for usammenlignbare størrelser, opplysninger som krevde tolkning, og konsekvenser av endring over tid i institusjonenes studieportefølje.

Anmodningen fra meg om å få tilsendt søkerlister, ble sendt i et felles brev til samtlige institusjoner. Tiden det tok før jeg mottok listene, kunne imidlertid variere sterkt. Det kunne 
derfor være en fare for at søkere, som kort tid etter søknadsfristen sa fra at de trakk søknaden, var blitt fjernet fra navnelisten før jeg mottok den, og at nye søkere kunne komme til etter at jeg hadde mottatt listene. Mitt inntrykk er imidlertid at navn som først var kommet inn på en søkerliste, ikke ble slettet, selv om vedkommende trakk seg, men trekket ble registrert i en egen kolonne, slik at opplysningene om søkeren ble bevart gjennom hele opptaksprosedyren. Navn som måtte finnes på en opptakskommisjonsliste fra mars måned, men ikke på søkerlisten fra januar, ble av meg plusset på i søkerlisten, slik at også disse ble tatt med i søkertallet. Dessuten var det alltid tilfeller av frammøtte til studiestart som ikke fantes på noen lister, dette kunne være personer som institusjoner med ledige studieplasser hadde sporet opp og gjennomført prøver med utenfor normale prosedyrer, noe som selvsagt er helt legitimt. Også disse studentene registrerte jeg som både søkere og frammøtte til opptaksprøver. Hvorvidt opptaksprosessen fant sted til andre tider og under andre omstendigheter enn "normalen", har jeg ikke betraktet som vesentlig.

Ovenfor nevnte Boysenrapport har tatt for gitt at slike utenomprosedyrale opptak ikke forekommer. Grunnen til dette kan være at rapporten ble ført i pennen av en representant for en av de største institusjonene, som har nok søkere på ventelister til å fylle studieplassene etter hvert som det takkes nei til tilbud om studieplass. De mindre institusjonene kan ha så få søkere på enkelte instrumenter at studieplasser står i fare for å bli stående tomme, og her er det vanlig med uformelle opptak helt fram til studiestart. I en fotnote under tabellen i Boysenrapportens punkt 4.5.4 heter det: "Tallene for HiA [daværende Høgskolen i Agder, min anm.] er gjengitt slik de er innrapportert, selv om det åpenbart må være feil at det er tatt opp flere (...) enn antallet som har søkt." Utsagnet er et eksempel på konklusjoner i Boysenrapporten som er basert på uvitenhet og feiltolkning av grunnlagsdata, og det er et uttrykk for den store forskjelligheten i prosedyrer og regelverk som preger konservatoriefeltet.

De fleste institusjonene var raske med å behandle forespørslene fra meg, mens et mindretall kunne være svært sene med å gi fra seg dataene. Måneder kunne komme og gå, gjentatte purringer til tross, før det endelig var mulig å få tilsendt listene. I ett tilfelle fikk jeg listene først etter "korporlig" og uanmeldt å ha møtt opp ved institusjonen selv. Hva årsaken kan være til dette? Kanskje en viss uvilje fra enkelte ansatte ved enkelte institusjoner mot å oppgi søkertallene til en ansatt ved en konkurrerende institusjon? Jeg velger å tolke dette annerledes; det er en ekstrabelastning for de ansatte å saksbehandle slike forespørsler; vårsemesteret er en travel tid for administrasjonen ved konservatorieutdanningene.

Når først søkerlistene var mottatt, var det en spesiell variant av uklarhet som genererte mye ekstraarbeid, nemlig den ulike praksisen fra institusjon til institusjon når det gjaldt 
registrering av søkere med to etternavn. Noen institusjoner plasserte begge etternavnene i kolonnen for etternavn, med mellomnavnet først, mens andre definerte det siste etternavnet som hovedetternavn. Dermed var det nesten umulig å oppdage at samme person sto oppført på to steder i basen. Det kunne bare oppdages ved møysommelig og gjentatt granskning, søking, sortering og korrigering. Jeg valgte å definere det siste etternavnet som hovedetternavnet.

En annen type uregelmessighet var søkere med fremmedartede, gjerne østeuropeiske navn og dermed for meg "uklart kjønn". I slike tilfeller brukte jeg nettet, fant tekster som inneholdt navnene og fant ut av hvilket kjønn som normalt var bærer av navnet ut fra sammenhengen i teksten.

En tredje type problemstilling var søkere med to eller flere førsteprioriteter. For 2009 var det seks personer som hadde førsteprioritet både på et klassisk instrument og et jazzrytmisk instrument. Jeg kunne ha valgt å definere disse som en tredje kategori, ved siden av entydig klassisk og entydig jazz-rytmisk. Da måtte jeg ha operert med to klart fremtredende og dominerende grupper pluss én forsvinnende liten gruppe, som bare ville ha fungert som "støy" i tabeller og grafikk. Jeg kunne også ha valgt å ekskludere disse seks fra databasen og kun inkludere søkere med ett entydig hovedinstrument. Siden dette ville ha medført at de nasjonale søkertallene ikke ble 100 prosent korrekte, har jeg tatt høyde for at disse personene også må inngå i søkertallene, men for å forenkle lesbarheten i fremstillingene har jeg tolket de seks som enten klassiske eller jazz-rytmiske. Jeg har dermed foretatt en kategorisering som det strengt tatt ikke er dekning for i materialet, en type "reduksjon av detaljer og mangfold" (Jacobsen 2000:398). Denne handlingen vil ikke påvirke tendenser og konklusjoner i vesentlig grad, siden de seks utgjør kun 0,7 prosent av den samlede søkermassen. Tre av de seks befant seg på en klassisk klasseliste samme høst, de ble registrert som klassiske søkere. Av de tre $\varnothing$ vrige fordelte jeg de to kvinnene på henholdsvis klassisk og jazz-rytmisk fordi kvinner er likt representert på søkerlistene til de to instrumentene; mannen plasserte jeg på klassisk fordi menn utgjør en større prosentandel på søkerlistene til klassisk sang, sammenlignet med søkerlistene til jazz-rytmisk sang.

Den viktigste endringen i løpet av datainnsamlingsperioden er at en av institusjonene fra og med 2008 avviklet ordningen med treårig faglærerutdanning. Søkere til denne institusjonen kunne dermed ikke velge mellom utøvende og pedagogisk utdanning fra første studieår. Dette betyr at empirien når det gjelder søkningen til pedagogiske studier, om den $\emptyset$ ker eller minsker, om det er forskjeller mellom klassisk og jazz-rytmisk, utgjør et tynnere grunnlag for slutninger, sammenlignet med de andre temaene som er tatt opp i undersøkelsen. Det innebærer igjen at en analyse av søkningen til pedagogiske grunnutdanninger, 
sammenlignet med utøvende, på basis av data fra alle de fire institusjonene som tidligere tilbød pedagogiske utdanninger fra første år, ikke lot seg gjennomføre. Analysen måtte baseres kun på dataene fra de tre institusjonene som fortsatt tilbyr pedagogiske grunnutdanninger fra første studieår. Nasjonalt sett ble det ikke nødvendigvis færre "pedsøkere" til det første studieåret fordi én institusjon sluttet å tilby faglærerutdanning; søkerne måtte bare fordele seg på tre i stedet for på fire institusjoner. Dessuten visste søkerne til den nevnte institusjonen at de fikk tilbud om pedagogisk komponent senere i studieforløpet. Men tendensene som det er mulig å trekke ut fra analysen av akkurat denne empirien, er basert kun på dataene fra tre institusjoner; de andre resultatene som fremstilles, er basert på analyser av data fra alle seks institusjonene.

Til tross for de nevnte mulige truslene mot pålitelighet og gyldighet, er det min oppfatning at databehandlingen og analysen kjennetegnes av et høyt nøyaktighetsnivå; dette på grunn av utallige dobbeltsjekker og krysskontroller, gjennomført av meg selv.

\section{Personvernproblematikk}

Lov om behandling av personopplysninger (Lovdata 2001), også kalt personopplysningsloven, og Forskningsetiske retningslinjer (NESH 2006) regulerer behandlingen av direkte personidentifiserende opplysninger. I mine e-poster til institusjonene gjorde jeg det tydelig, ikke bare hvilke data jeg trengte, men også hvilke jeg ikke trengte, og som ikke måtte sendes over nettet. Allikevel mottok jeg flere ganger hele rådatabasene, med sensitive opplysninger som fødselsnumre, adresser, navn på nærmeste pårørende og sykdomsgrunn som årsak til fravær på opptaksprøven. Hjemmelen for den enkelte institusjon for å gjøre dette finnes i personopplysningslovens $\S \S 8$ og 9 , der det heter at også sensitive personopplysninger kan behandles og utleveres dersom slik behandling er nødvendig for å utføre en oppgave av "allmenn interesse" (§ 8) og behandlingen er nødvendig for "historiske, statistiske eller vitenskapelige formål” ( $§$ 9). Praksisen stred imidlertid imot $\S 12$, som uttrykker at fødselsnumre kun er tillatt å videreformidle dersom det er nødvendig i identifiseringsøyemed, hvilket ikke var tilfelle i min undersøkelse.

Jeg hadde ingen direkte kontakt med de registrerte på individnivå. Det var ikke mulig å innhente samtykke fra hver enkelt søker for å be om tillatelse til å telle dem opp, mange hadde hjemmeadresser i land utenom Norge. Dette ble også erkjent av Personvernombudet: "Da prosjektleder ikke har fått utlevert adresser til utvalget vil det heller ikke være mulig for ham å overholde informasjonsplikten sin overfor de allerede registrerte personene." Ombudet sier videre: 
Det legges også vekt ved dels at det ikke behandles sensitive personopplysninger og dels at det i dette tilfelle er absolutt nødvendig at samtlige i utvalget blir registrert. Ved innhenting av samtykke vil det alltid være noen som av forskjellige grunner ikke avgir samtykke, og i dette tilfelle ville bortfall av registrerte umuliggjøre studien.

Min korrespondanse foregikk derfor kun med de seks institusjonene. Avtalen med ombudet var at det måtte gis en generell informasjon om at søkerne til konservatoriesektoren var omfattet av en nasjonal søkerundersøkelse. Denne informasjonen ble formulert av meg og sendt mine institusjonskontakter med anmodning om videreformidling. Dette kunne skje enten via innkallingsbrevene som søkerne mottok før opptaksprøvene, eller via oppslag på frammøtestedet for opptaksprøvene. At denne informasjonen ble videreformidlet, har jeg selv registrert kun ved én institusjon; jeg har ingen garanti for at informasjonen kom samtlige registrerte for $\varnothing$ re.

\section{Opptaksprosessen våren 2009}

\section{Søknader}

Som nevnt innledningsvis: Når man summerer tallene i DBH-basen for alle søknadene som den enkelte institusjon har rapportert inn, får man for 2009 tallet 2058. Av overskriften på tabellen er det nærliggende å tolke dette tallet som antall søknader. Ifølge mine analyser på individnivå er dette feil. Tallet 2058 omfatter antall avkryssede svaralternativer i søknadsskjemaene, altså summen av alle mulige ønsker fra søkerne, for eksempel ønskene om faglærer hvis de ikke kommer inn på utøvende, ønskene om klassisk hvis de ikke kommer inn på jazz-rytmisk, og alt dette multiplisert med antall institusjoner den enkelte søkeren har søkt. Dette er det eneste nasjonale tallet jeg kan få ut av DBH, det totale antall avkryssinger på søknadsskjemaene. Fordi kunnskapen om dette antallet har få anvendelsesområder, utelater jeg å omtale dette nivået i fortsettelsen.

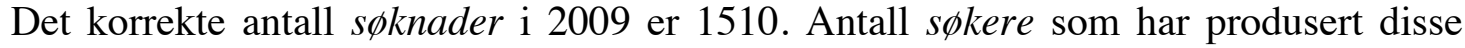
søknadene, er langt mindre. Men også det neste nivået er nyttig å kjenne til og analysere, nemlig antall frammфtte til opptaksprøvene. Dette tallet er nemlig et ganske annet enn tallet på søkere. Det er de sistnevnte jeg betrakter som reelle søkere, de som faktisk møter opp med fiolinen eller el-bassen og fremstiller seg til opptaksprøver. Som nevnt valgte jeg å ikke be om data på antall kvalifiserte, mens antall søkere som ble studenter, og som altså møtte fram til første år på en grunnutdanning samme høst, inngår i datamaterialet. 
Nedenfor behandles de tre hovednivåene eller -fasene i opptaksprosessen, først

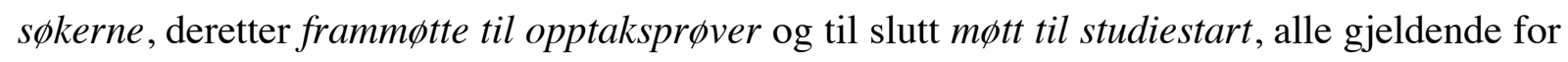
opptaksåret 2009.

\section{Søkere}

Tematikken i denne fremstillingen omfatter antall personer som søkte de utøvende musikkutdanningene i Norge i 2009, og hvordan denne gruppen fordeler seg på sjanger, antall søkte studiesteder, kjønn og instrumenter. Selv om jeg oppfatter frammøtte-tallene som mest interessante, fordi jeg ser på dem som møter fram til opptaksprøvene, som de reelle søkerne, viser jeg også til en del funn på søkernivå. Grunnen til dette er at det er på søkernivå det er mulig å sammenligne tallene med noen av de rapportene jeg har referert til.

Det korrekte tallet på antall søknader er altså 1510 for opptaksåret 2009. Dette tallet fremkommer ved å summere alle søkerlistene fra institusjonene. Tallet omfattet 795 eller 53 prosent jazz-rytmiske søknader og 717 eller 47 prosent klassiske søknader, en viss, men ikke vesentlig forskjell på søknadsnivå. Antall søkere som har produsert disse søknadene, er imidlertid bare 907 for studieåret 2009; 456 jazz-rytmiske og 451 klassiske søkere, altså ingen nevneverdig forskjell mellom de to gruppene på søkernivå. 907 søkere tilsvarer 60 prosent av søknadene, hvilket tilsvarer et aritmetisk gjennomsnitt på litt under 1,7 søknader per søker. Dette tallet ser i utgangspunktet ut til å samsvare med forutsetningene i fellesbrosjyren fra det nasjonale fagrådet for utøvende musikkutdanning og musikkvitenskap, der det heter at en og samme søker bare kan søke én av de fem institusjonene som har felles opptaksuke, men i tillegg også de to andre institusjonene som ikke omfattes av denne samordningen. Hvis vi ser på fordelingen av den jazz-rytmiske og den klassiske søkergruppen på antall søkte institusjoner, blir imidlertid dette bildet mer nyansert, som figuren nedenfor viser.

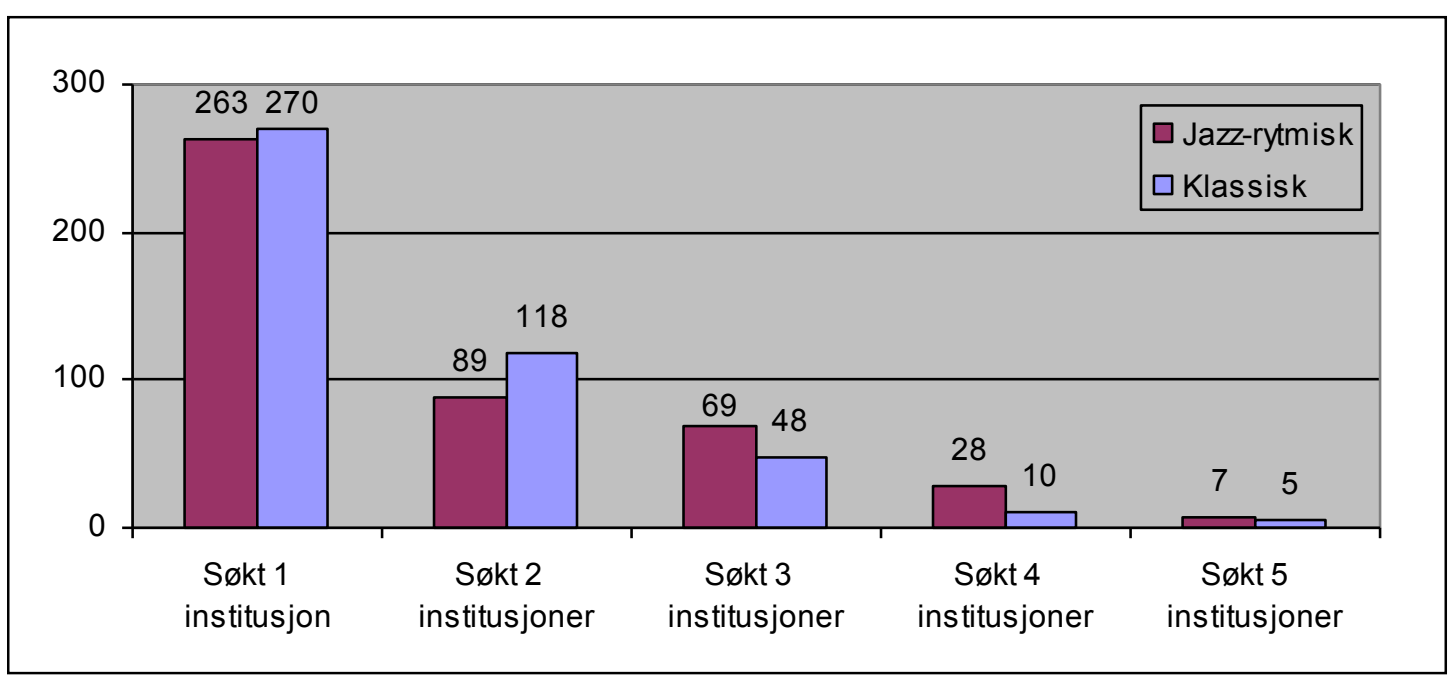


Figur 1 Den nasjonale søkermassen i Norge i 2009. Fordelingen av jazz-rytmiske og klassiske søkere på antall søkte institusjoner. Absolutte tall. $\mathrm{N}=907$.

Figur 1 viser at de klassiske søkerne dominerer blant dem som har søkt opptak ved én eller to institusjoner, mens jazz-rytmiske søkere er i flertall ved søkning til tre eller flere institusjoner. Selv om 104 av de jazz-rytmiske søkerne produserer noen flere søknader enn de klassiske, litt over 1,7 mot litt under 1,6 søknader i gjennomsnitt per person, anser jeg ikke disse forskjellene for å være vesentlige. I hovedavsnitt 4 undersøker jeg om dette forholdet har endret seg siden 2004.

Men hvorfor søkes det til flere institusjoner? Begrunnelsene kjenner jeg ikke, men de henger ventelig sammen med en forestilling om at det vil lønne seg å søke flere steder; at en slik strategi vil gi uttelling i form av økt sjanse til studieplass. I kapittel 3 og 4 drøftes andelen av søkerne som fikk studieplass høsten 2009, og om det faktisk var slik i 2009 at det lønte seg å søke flere institusjoner.

Man kan også spørre seg hvor stor andel av søkerne som er felles for listene fra for eksempel to ulike institusjoner. Siden jeg ikke ønsker å si noe om søkningen til enkeltinstitusjoner, kan jeg bare si at stikkprøver har vist at over 40 prosent av søkerne til én institusjon kan stå på søkerlistene også til en annen institusjon.

Boysenrapporten oppgir at det var 965 søkere til klassiske og jazz-rytmiske grunnutdanninger i 1999 (pkt. 4.5.4). Utvalget bak rapporten forutsatte som nevnt at dobbeltsøkning ikke forekommer, men jeg anser det som sannsynlig at slik praksis forekom i stor skala også på 1990-tallet (jeg var selv opptaksansvarlig ved et norsk konservatorium i tidsrommet 1993-1996). Jeg betrakter derfor tallet 965 som et søknadstall. Tar man høyde for parallells $\varnothing \mathrm{kning}$ og bruker man det samme forholdstallet mellom søknader og søkere som funnene ti år senere tilsa, nemlig at antall søkere er ca. 60 prosent av antall søknader, får vi at det egentlige, nasjonale antall søkere for 1999 var 579. Dette tallet kan selvsagt ikke brukes til noe som helst, men jeg har grunn til å tro at det siste tallet er nærmere sannheten enn 965 for opptaksåret 1999. Uansett er mange av funnene som er referert i Boysenrapportens punkt 4.5.4 og 4.5.5 lite anvendelige som sammenligningsgrunnlag eller som utgangspunkt for videre unders $\varnothing$ kelser av søkningen til konservatoriesektoren i Norge, fordi de baserer seg på en antakelse om at dobbelts $\varnothing$ kning ikke forekommer konservatoriene imellom, en antakelse som min undersøkelse har vist er feil. Mange av funnene i Boysenrapporten, og særlig når det gjelder opptaksprosenter, kvinneandeler og kjønnsmessige forskjeller i formelle og musikalske kvalifikasjoner, baserer seg på en tolkning av innsendte grunnlagsdata fra 
institusjonene som vi nå, etter å ha studert søkerdata på individnivå, kan slå fast gir feil konklusjoner.

Av det samlede antall søkere på 907 i 2009 var 46 prosent kvinner, 54 prosent menn. De klassiske søkerne fordelte seg på 60 prosent kvinner og 40 prosent menn, mens de jazzrytmiske søkerne fordelte seg på 31 prosent kvinner og 69 prosent menn. Altså er ca. to tredeler av søkermassen til jazz-rytmiske studier menn, ca. en tredel er kvinner, mens tre femdeler av den klassiske søkermassen er kvinner, og to femdeler er menn. Det er dermed fortsatt betydelige kjønnsmessige forskjeller mellom søkningen til henholdsvis klassiske og jazz-rytmiske studier for opptaksåret 2009. Disse forskjellene er ikke overraskende. Brändström et al. (1995:167-168), KUF (1999 pkt. 4.5.5) og Tønsberg (2000:34) forteller alle om betydelig overvekt av menn som søkere til og som studenter på jazz-rytmiske utdanninger. Men det som er interessant å finne ut av, er om kvinneandelen på sistnevnte studieforløp kanskje er i ferd med å stige. I hovedavsnitt 4 ser jeg på dette i lys av funnene for 2004 og 2006 og svarer på spørsmålet om det har vært en økning av andelen kvinner blant jazzrytmiske søkere de siste årene.

Hvordan søkerne til konservatoriesektoren i Norge i 2009 fordeler seg på instrument, går fram av figur 2 nedenfor. Klassisk og jazz-rytmisk sang utgjør 30 prosent av alle søkerne, mens tangentinstrumenter i begge sjangere utgjør 11 prosent. Tre av ti søker altså vokale studier, mens en tidel søker klaverinstrumenter.

Den sjangermessige fordelingen kommer til uttrykk ved en noe ulik profil. Av de 13 jazz-rytmiske instrumentene det var mulig å søke på i 2009, er alle de fem typiske bandinstrumentene, vokal, gitar, trommer, tangent og bass, inne på listen over instrumenter med flere enn 40 søkere per instrument, noe som jeg vil kalle høye søkertall. De åtte øvrige jazzrytmiske instrumentene har relativt lave søkertall. Denne søkergruppen klumper seg altså sammen om noen få instrumenter. Den klassiske søkergruppen fordeler seg noe jevnere på hele 21 instrumenter, og kommer derfor ikke til syne i figuren nedenfor (en mer fullstendig oversikt finnes i figur 5). 


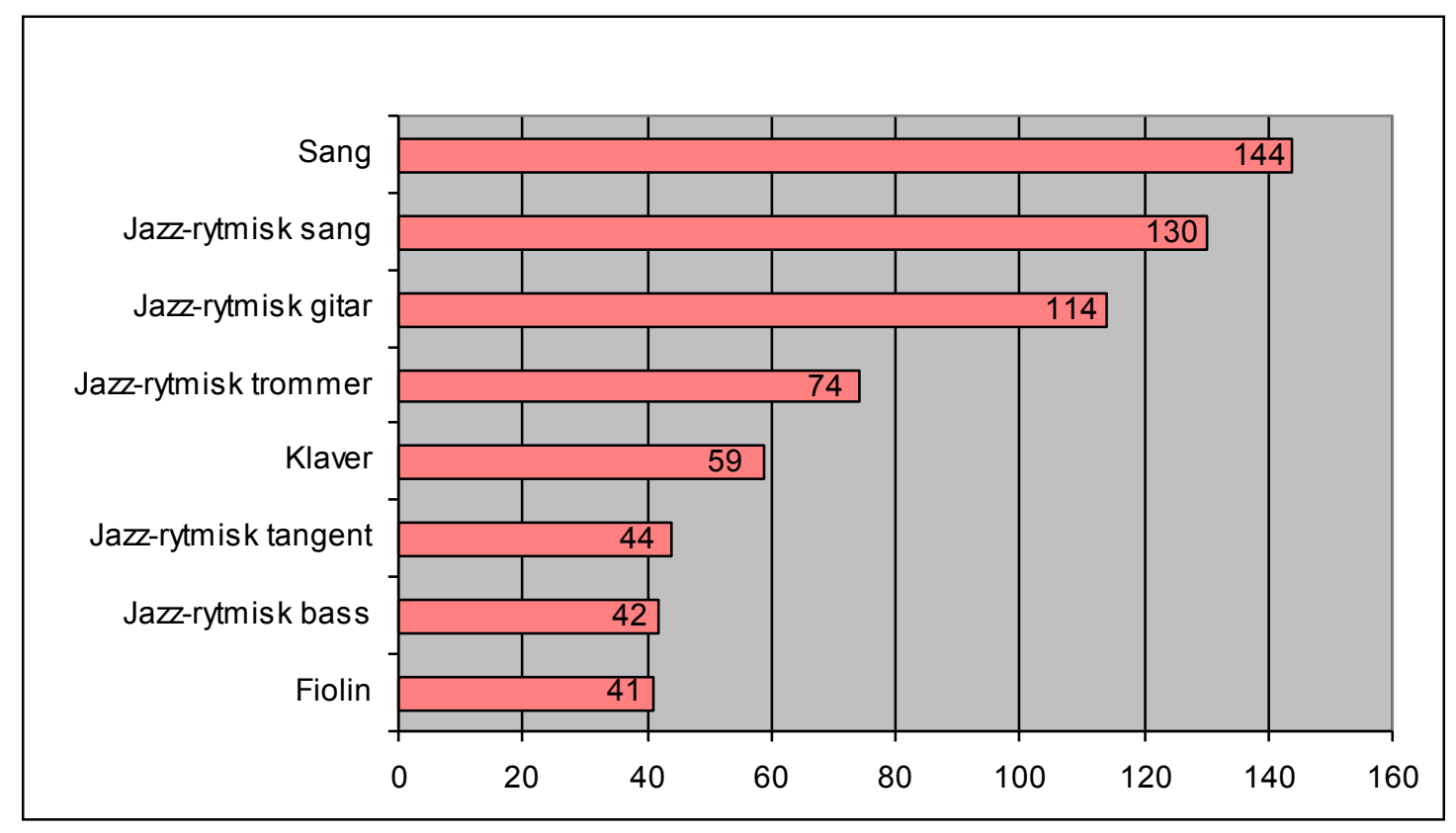

Figur 2 Den nasjonale søkermassen i Norge i 2009. Søkerne fordelt på instrument. Kun instrumenter med flere enn 40 søkere er vist. Absolutte tall. $\mathrm{N}=907$.

Hvordan er kjønnsfordelingen innenfor de enkelte instrumentene? Det er en typisk og forutsigbar kjønnsfordeling i mannlige søkeres favør når det gjelder de jazz-rytmiske instrumentene gitar, trommer og tangent, mens jazz-rytmisk sang ble søkt av 18 prosent menn og 82 prosent kvinner. Innenfor klassisk sang er forholdet et litt annet: I 2009 var én av fire sangsøkere menn. I hovedkapittel 4 drøfter jeg om denne andelen har endret seg de siste årene.

En oppsummering av funnene i søkergruppen viser følgende: Antall søkere for studieåret 2009 er 907, fordelt på 456 jazz-rytmiske og 451 klassiske, altså ingen nevneverdig forskjell i størrelsen på de to gruppene. De klassiske søkerne dominerer blant dem som har søkt én eller to institusjoner, mens de jazz-rytmiske søkerne er i flertall blant dem som har søkt tre eller flere institusjoner. Tre av ti søkere ønsker seg inn på vokale studier; én tidel søker klaverinstrumenter. Blant de klassiske instrumentene er det høye søkertall på sang, klaver og fiolin; på jazz-rytmisk er alle de fem tradisjonelle band-instrumentene (vokal, gitar, trommer, tangent og bass) blant instrumentene med flere enn 40 søkere per instrument.

\section{Møtt til opptaksprøver}

Tematikken i dette avsnittet omfatter frafallsproblematikk og antall frammøtte til opptaksprøver fordelt på sjanger, kjønn og studiesteder. Med frafall mener jeg differansen mellom antall søkere og antall frammøtte til opptaksprøver.

I 2009 møtte 606 av de 907 søkerne fram til opptaksprøver. Dette utgjør 67 prosent. En tredel av dem som har fylt ut ett eller flere søknadsskjemaer til konservatoriesektoren, 
møter altså ikke opp og fremstiller seg til opptaksprøvene. Dette er ikke en høy andel hvis man sammenligner med tall fra Samordna Opptak for 1998, da frafallet var på 37 prosent (Brandt et al. 2005:37). Men det tallet omfatter frafallet for alle de tre fasene som er nevnt under kapittel 1.1. Her gjelder frafallsandelen på 33 prosent bare det at søkerne lar være å møte til opptaksprøvene, i tillegg kommer frafall på grunn av ikke-godkjente opptaksprøver, fordi det svares nei til tilbud om studieplass, og på grunn av at ikke alle som har takket ja til tilbud, møter fram ved studiestart samme høst.

Hva kan årsaken være til at 301 personer ikke møtte til opptaksprøver i 2009? Mine data omfatter ikke slike aspekter, men mulige forklaringer kan være at noen ble avvist, de hadde kanskje ikke godkjent studiekompetanse; noen ble syke, de fikk trolig sjansen til opptak senere på våren; noen fant ut at de ikke hadde det tekniske eller musikalske nivå som de antok var forventet av dem; noen endret studieønsket og avbrøt derfor opptaksprosessen i løpet av månedene mellom søknadsfrist og opptaksprøver; noen var allerede i en annen utdanning og valgte å fortsette i den.

Når det gjelder ulikheter mellom ulike grupper av frammøtte til opptaksprøvene, var det ingen vesentlig sjangermessig forskjell. Både av de jazz-rytmiske og de klassiske søkerne møtte ca. to tredeler opp til opptaksprøvene i 2009 (307 jazz, 299 klass.). Kjønnsmessig var det derimot en viss forskjell, da 346 av de mannlige søkerne møtte fram (70 prosent), mot 260 av kvinnene (63 prosent). Av de rytmiske søkerne er det høyere frammøteprosent blant kvinnene, 69 prosent, enn blant mennene, 62 prosent. Av de klassiske søkerne er det lavere frammøteprosent blant kvinnene, 63 prosent, enn blant mennene, der 71 prosent møtte fram. I hovedavsnitt 4 settes disse funnene i sammenheng med opptaksårene 2004 og 2006, og det vurderes om det er mulig å se endringer over tid på disse områdene.

Funnene når det gjelder parallell- eller dobbeltframmøte til opptaksprøver, er et hovedanliggende i unders $\varnothing$ kelsen. Fordelingen som ble vist i figur 1 ovenfor, over antall søkte studiesteder, har sin tilsvarende fordeling i antall oppsøkte studiesteder, som vises i figur 3 nedenfor. 


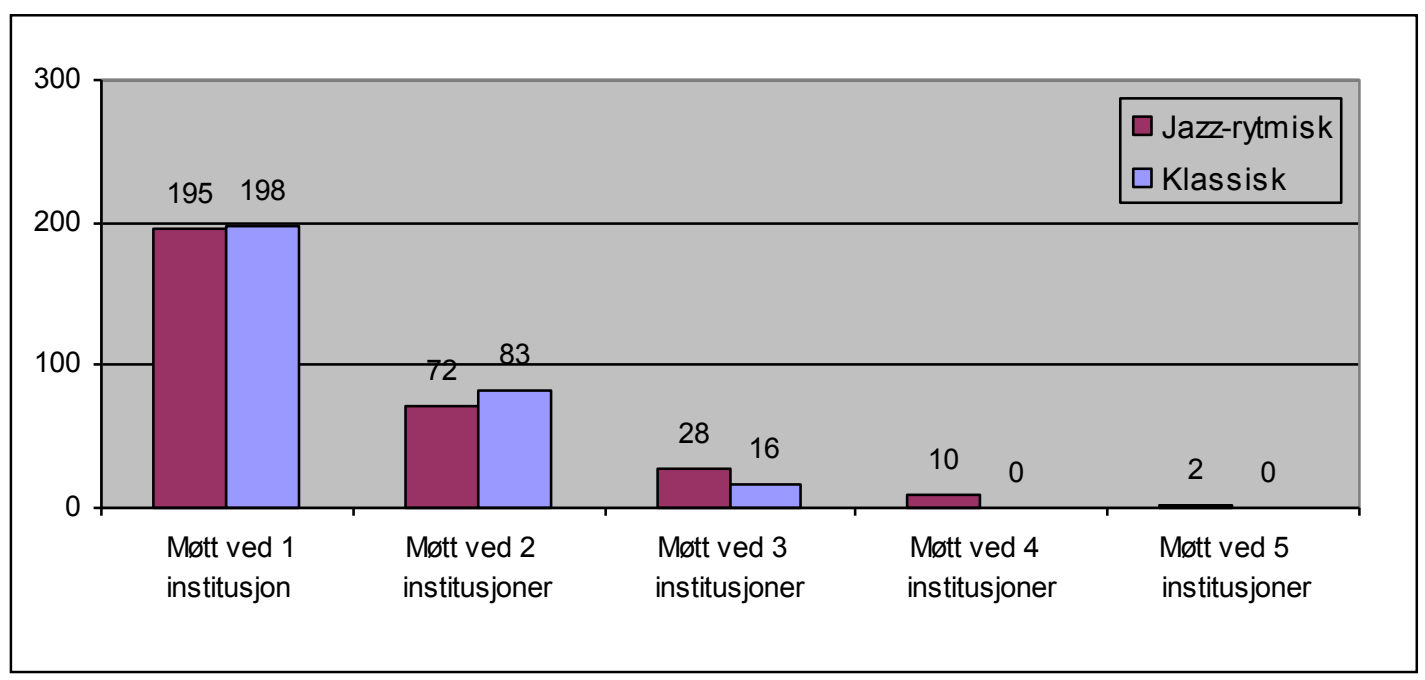

Figur 3 En oversikt over antall institusjoner jazz-rytmiske og klassiske søkere møtte fram til opptaksprøver ved. Absolutte tall. $\mathrm{N}=606$.

Figur 3 viser, som figur 1, at de klassiske søkerne dominerer blant dem som har møtt til opptaksprøver ved én eller to institusjoner, mens de jazz-rytmiske søkerne er i flertall blant dem som har møtt til tre eller flere institusjoner. Noen søkere går altså igjen ved nesten alle opptaksprøvene. Også her kan man spørre seg om det "lønner seg” å møte fram til flere opptaksprøver, hvilket blir belyst under 4.3 nedenfor.

En oppsummering av funnene når det gjelder møtt til opptaksprøver, viser at en tredel av søkerne som står på listene noen uker etter søknadsfristen, ikke finnes igjen på listene over frammøtte til opptaksprøvene. Det er de to faktorene parallellsøkning og frafall underveis i søkningsprosessen som utgjør forskjellen mellom antall søknader og antall frammøtte til opptaksprøver.

\section{Møtt til studiestart}

Denne fremstillingen dreier seg om den gruppen av søkere som, etter å ha kommet seg gjennom opptaksprosessen våren 2009, ble studenter, idet de møtte fram til studiestart $\mathrm{i}$ august samme år. Tematikken omfatter sjanger, kjønn, instrument og balansen mellom utøvende og pedagogisk studieretning.

Av 907 søkere og 606 frammøtte til opptaksprøver møtte 188 personer til studiestart; en andel på 21 prosent av antall søkere, 31 prosent av antall frammøtte til opptaksprøver. De 188 fordeler seg på sjanger med 69 jazz-rytmiske og 119 klassiske studenter. Dette innebærer at mens "styrkeforholdet" mellom jazz-rytmisk og klassisk har vært tilnærmet jevnt både når det gjelder søknader (53 prosent jazz, 47 prosent klass.), søkere (helt likt) og antall frammøtte til opptaksprøver (51:49), er det når det kommer til hvem som til slutt får tilbud om, takker ja til og møter fram til en studieplass, at forskjellene blir betydelige. Kun 37 prosent av 
førsteårsstudentene er jazz-rytmiske, 63 prosent er klassiske. Figur 4 nedenfor fremstiller disse forholdene for 2009:

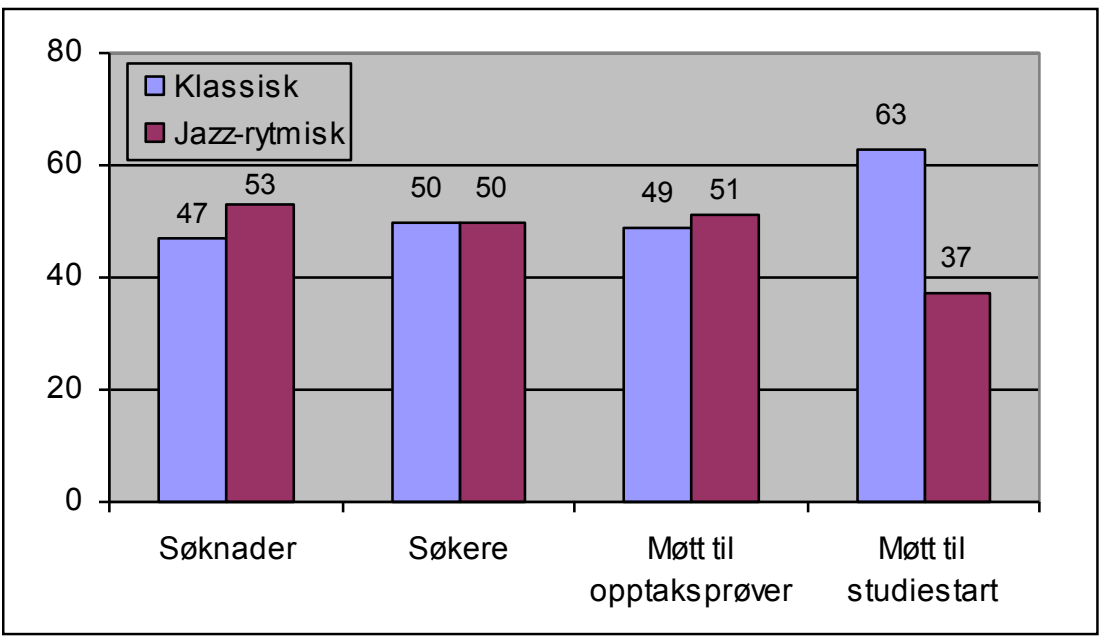

Figur 4 En fremstilling av andelene i 2009 av jazz-rytmiske og klassiske søknader, søkere, møtt til opptaksprøver og møtt til studiestart. Prosentuerte verdier.

Selv om det er et høyere antall jazz-rytmiske frammøtte til opptaksprøvene enn klassiske, er det et helt annet forhold når det kommer til hvilken gruppe som besitter de fleste studieplassene. Dette er imidlertid ikke annet enn ventet, alle tilgjengelige kilder sier det samme: Utdanningskapasiteten innen rytmiske sjangere er mindre enn innenfor klassiske, og den er for liten i forhold til etterspørselen (KUF 1999 § 8.4, KUF 1996).

Denne store forskjellen mellom jazz-rytmisk og klassisk får store utslag på enkelte områder, for eksempel kjønnsfordelingen. Av 188 førsteårsstudenter høsten 1999 var 115 menn og 73 kvinner, altså en fordeling på 61 prosent menn og 39 prosent kvinner. I forhold til de 346 frammøtte mennene til opptaksprøvene betyr dette at disse hadde 33 prosent sjanse til studieplass; kvinnene hadde 28 prosent sjanse til studieplass (av 260 frammøtte kvinner). En forskjell på fem prosentpoeng i mennenes favør er allikevel ikke mye. Av de 115 mennene var 56 jazz-rytmiske og 59 klassiske, en svært jevn fordeling. Av de 73 kvinnene som ble studenter, var 13 på jazz-rytmisk og 60 på klassisk. Den klassiske gruppen på 119 studenter består altså av omtrent like mange kvinner som menn (60:59), mens det i den jazz-rytmiske gruppen er mer enn fire ganger så mange menn som kvinner. Forholdet 115:73 i mennenes favør i førsteårsgruppen blir drøftet i avsnitt 5.4 nedenfor, der temaet er en mulig utvikling over tid. Instrumentfordelingen blant førsteårsstudentene høsten 2009 går fram av figur 5 nedenfor. 


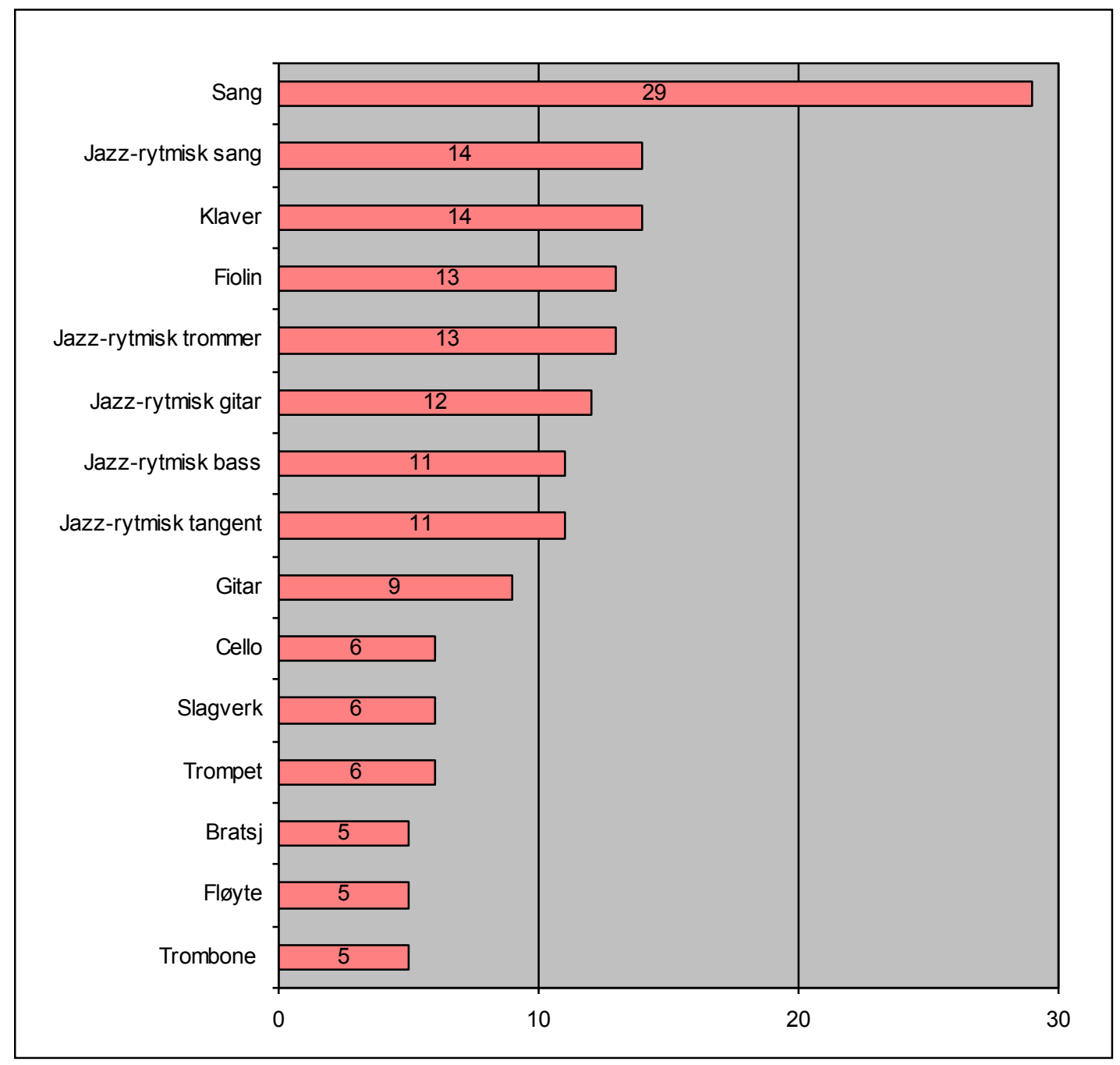

Figur 5 Instrumentfordelingen høsten 2009 blant jazz-rytmiske og klassiske førsteårsstudenter. Kun de 15 instrumentene med fem eller flere studenter er tatt med. De $\varnothing v$ vrige 13 instrumentene, 10 klassiske og 3 jazz-rytmiske, har fra én til fire studenter. Absolutte tall. $\mathrm{N}=188$.

Som figuren viser, er det et uforholdsmessig stort antall studenter som studerer klassisk sang i Norge i dag. De andre instrumentene har et langt jevnere antall studenter. Hva kan denne voldsomme skjevheten komme av? Det henger selvsagt sammen med opptakskapasiteten på hvert enkelt instrument; klassisk sang hadde altså mer enn dobbelt så høy kapasitet for inntak av nye studenter som de nærmeste instrumentene på oversikten, uten at de samfunnsmessige behovene for kompetanse i klassisk sang nødvendigvis er høyere enn innenfor eksempelvis jazz-rytmisk sang, klassisk klaver eller fiolin.

En oppsummering av funnene når det gjelder møtt til studiestart for 2009, viser følgende: Nesten en tredel av antall frammøtte til opptaksprøver fikk studieplass. Av disse var 37 prosent jazz-rytmiske, 63 prosent var klassiske. I den jazz-rytmiske gruppen var det mer enn fire ganger så mange menn som kvinner, mens det var kjønnsmessig lik balanse på 
klassisk. Mennene hadde litt større sjanse på studieplass enn kvinnene. Når det gjelder på hvilket instrument det var størst sjanse til opptak, var vinnerne gitar og strykeinstrumenter, men det var klassisk sang som hadde det største antall studenter; her var det over dobbelt så mange som de to neste på listen: jazz-rytmisk sang og klassisk klaver. Mannlige jazz-rytmiske søkere gjennomførte flest opptaksprøver og hadde størst uttelling i form av studieplasser.

\section{Utviklingen i tidsrommet 2004-2009}

I det følgende trekker jeg først linjene bakover til 2006 og 2004, og peker på mulige tendenser over tid. Deretter antyder jeg noen mulige fremtidige konsekvenser av disse tendensene. Jeg strukturerer fremstillingen etter disse fire nivåene: søknader, søkere, møtt til opptaksprøver og møtt til studiestart.

Det som er viktig å påpeke med tallene i tabellene nedenfor, er at siden vi ikke kjenner dataene for 2005, 2007 og 2008, er det ikke mulig å slå fast noe om en eventuell jevn utvikling, enten det dreier seg om et antall eller en andel, enten en verdi ser ut til å gå oppover eller nedover, i løpet av de tre årene. Derfor bruker jeg uttrykk som utviklingstendenser og utviklingstrekk når jeg peker på forhold som jeg mener er av betydning. Det som allikevel må kunne fremholdes som en styrke ved funnene, er at de er basert på absolutte tall. Unders $\varnothing$ kelsen er ikke en utvalgsunders $\varnothing$ kelse, den er en populasjonsunders $\varnothing$ kelse. Bak hver enkelt tallstørrelse står et absolutt antall fysiske, individuelle personer; kvinner og menn. Så når jeg slår fast at den relativt jevne andelen av kvinner og menn som møtte til studiestart i 2004, har endret seg til en betydelig overvekt av menn i 2009, så er ikke dette en antakelse basert på generalisering ut fra et utvalg, det er faktisk slik tallene var i 2004 og 2009. Så må man vurdere hvilke konsekvenser man vil trekke av det.

\section{Søknader}

Antall søknader i de tre årene som undersøkelsen omfatter, fremgår av tabell 1:

\begin{tabular}{|ll|c|c|c|}
\hline & $\mathbf{2 0 0 4}$ & $\mathbf{2 0 0 6}$ & $\mathbf{2 0 0 9}$ \\
\hline Søknader - antall & 1227 & 1182 & 1510 \\
\hline Kjønn & - kvinner & 610 & 536 & 675 \\
& - menn & 617 & 616 & 835 \\
\hline \multirow{2}{*}{ Sjanger } & - klassisk & 594 & 597 & 716 \\
& - jazz-rytmisk & 633 & 585 & 794 \\
\hline
\end{tabular}

Tabell 1 Det nasjonale antall søknader for årene 2004, 2006 og 2009. Absolutte tall.

Et hovedtrekk ved utviklingen i tidsrommet 2004-2009 er en betydelig $\varnothing \mathrm{kning} \mathrm{i}$ antall søknader; hele 19 prosent $\varnothing$ kning fra 2004 til 2009. For 2006 er tallene imidlertid betydelig 
lavere. Det er bare antall klassiske søknader og søknader fra menn som holder seg stabilt fra 2004 til 2006. I forholdet mellom sjangerne er det nokså stabilt fra år til år, med en liten overvekt på jazz-rytmisk side hvis man ser de tre årene i sammenheng (51 prosent jazzrytmisk mot 49 prosent klassisk).

\section{Søkere}

Antall søkere i de tre årene som undersøkelsen omfatter, fremgår av tabell 2:

\begin{tabular}{|ll|c|c|c|}
\hline & $\mathbf{2 0 0 4}$ & $\mathbf{2 0 0 6}$ & $\mathbf{2 0 0 9}$ \\
\hline Søkere - antall & 802 & 757 & 907 \\
\hline Sjanger & - klassisk & 418 & 404 & 451 \\
& - jazz-rytmisk & 384 & 353 & 456 \\
\hline Kjønn & - kvinner & 400 & 373 & 414 \\
& - menn & 402 & 384 & 493 \\
\hline
\end{tabular}

Tabell 2 Det nasjonale antall søkere for årene 2004, 2006 og 2009. Absolutte tall.

En prosentuering av andelen søkere sett i forhold til antall søknader viser en nedgang fra 65 til 60 prosent fra 2004 til 2009. Dette innebærer at søkerne produserer stadig flere søknader. Selv om stigningen ikke er dramatisk, bare en endring fra gjennomsnittlig 1,5 søknader per søker i 2004 til 1,7 i 2009, så er det allikevel noe jeg vil kalle et utviklingstrekk, og man må regne med en mulighet for fortsatt økning her. Både når det gjelder kjønn og sjanger, er det en nedgang fra 2004 til 2006 og en betydelig økning igjen fra 2006. Fra 2004 øker søkergruppen med 13 prosent. Den gruppen som bidrar sterkest til denne utviklingen, er mennene, som øker med 23 prosent fra 2004; til sammenligning øker kvinnene med bare 4 prosent i samme tidsrom. På jazz-rytmisk side utgjør økningen fra 2004 til 200919 prosent, mot 9 prosent på klassisk side.

\section{Møtt til opptaksprøver}

Antall fremmфtte til opptaksprøver i de tre årene som undersøkelsen omfatter, fremgår av tabell 3:

\begin{tabular}{|ll|c|c|c|}
\hline & & $\mathbf{2 0 0 4}$ & $\mathbf{2 0 0 6}$ & $\mathbf{2 0 0 9}$ \\
\hline Frammøtte til opptaksprøver - antall & 548 & 537 & 606 \\
\hline Sjanger & - klassisk & 297 & 290 & 299 \\
& - jazz-rytmisk & 251 & 247 & 307 \\
\hline \multirow{2}{*}{ Kjønn } & - kvinner & 277 & 258 & 261 \\
& - menn & 271 & 279 & 345 \\
\hline
\end{tabular}

Tabell 3 Det nasjonale antall frammøtte til opptaksprøver for årene 2004, 2006 og 2009. Absolutte tall. 
Hvor mange av søkerne som møter fram til opptaksprøvene varierer lite fra år til år, fra 68 prosent i 2004, via 71 prosent i 2006 til 67 prosent i 2009. Det er altså ingen særlige endringer over tid når det gjelder frafall av søkere fram mot opptaksprøvene. I gjennomgangen av frammøttetallene ovenfor fant jeg at det ikke var noe sjangermessig avvik av betydning fra frafallsgjennomsnittet for 2009. Hvis man ser dette over tid, er det en tendens til at andelen klassiske som møter fram til opptaksprøvene, er større enn andelen jazz-rytmiske som møter fram (70:67 prosent). Kjønnsmessig sett er det en tendens at kvinneandelen av søkerne går ned (fra 69 prosent i 2004 og 2006 til 63 i 2009), mens andelen menn går opp (67/73/70), når det gjelder hvor mange som møter opp til opptaksprøvene. Eller for å se på de absolutte tallene: I 2009 var det 74 flere menn og 16 farre kvinner som møtte til opptaksprøver, sammenlignet med 2004. Den sterke veksten i antall mannlige søkere går igjen på alle nivåer og er et slående funn, i kontrast til kvinneantallet, som er preget av stagnasjon og til dels nedgang. Det store bildet viser uansett at et frafall fram mot opptaksprøvene på rundt en tredel av søkermassen holder seg ganske stabilt fra år til år.

\section{Møtt til studiestart}

Antall søkere som har fått tilbud om og takket ja til studieplass, og som møter til studiestart samme høst som opptaksåret, fremgår av tabell 4.

\begin{tabular}{|c|c|c|c|c|}
\hline \multirow{2}{*}{\multicolumn{2}{|c|}{ Studenter - antall møtt til studiestart }} & \multirow{2}{*}{$\begin{array}{c}2004 \\
171\end{array}$} & \multirow{2}{*}{$\begin{array}{c}2006 \\
175\end{array}$} & \multirow{2}{*}{$\begin{array}{c}2009 \\
188\end{array}$} \\
\hline & & & & \\
\hline Sjanger & $\begin{array}{l}\text { - klassisk } \\
\text { - jazz-rytmisk }\end{array}$ & $\begin{array}{c}111 \\
60\end{array}$ & $\begin{array}{c}113 \\
62\end{array}$ & $\begin{array}{c}119 \\
69\end{array}$ \\
\hline Kjønn & $\begin{array}{l}\text { - kvinner } \\
\text { - menn }\end{array}$ & $\begin{array}{l}87 \\
84\end{array}$ & $\begin{array}{l}84 \\
91\end{array}$ & $\begin{array}{c}73 \\
115\end{array}$ \\
\hline
\end{tabular}

Tabell 4 Det nasjonale antall møtt til studiestart for årene 2004, 2006 og 2009. Absolutte tall.

Mens det for søknader, søkere og frammøtte til opptaksprøver var en nedgang i antallene for 2006, får vi når det gjelder antall møtt til studiestart, et noe annet bilde. Her er det $\varnothing \mathrm{kning} \mathrm{i}$ antallet i alle tre årene, 10 prosents $\varnothing$ kning fra 2004 til 2009. Hvor mange av dem som møtte til opptaksprøver, møtte også til studiestart? Både i 2004 og i 2009 fikk 31 prosent studieplass av dem som møtte til opptaksprøver, så den andelen ligger ganske stabilt.

Som nevnt tidligere, er Boysenrapportens tall sammenlignbare med tallene fra min egen undersøkelse når det gjelder enkelte opptakstall. I vedlegg $3 \mathrm{i}$ denne rapporten finnes opptakstall fra 1996 og 1997. Disse tallene fra siste halvdel av 1990-tallet satt sammen i en tabell med tallene fra 2000-tallet viser utviklingen over et tidsrom på 13 år: 


\begin{tabular}{|c|c|c|c|c|c|}
\hline & 1996 & 1997 & 2004 & 2006 & 2009 \\
\hline Studenter - antall møtt til studiestart & 201 & 199 & 171 & 175 & 188 \\
\hline $\begin{array}{ll}\text { Sjanger } & - \text { klassisk } \\
& - \text { jazz-rytmisk }\end{array}$ & $\begin{array}{r}170 \\
31\end{array}$ & $\begin{array}{r}169 \\
30\end{array}$ & $\begin{array}{r}111 \\
60\end{array}$ & $\begin{array}{r}113 \\
62\end{array}$ & $\begin{array}{r}119 \\
69\end{array}$ \\
\hline
\end{tabular}

Tabell 5 Antall studenter tatt opp på en grunnutdanning, i fem ulike år, fordelt på klassisk og jazz-rytmisk. Absolutte tall.

Tabellen viser at tallene som gjelder totalt antall førsteårsstudenter, lå høyere i 1996 og 1997 enn de gjør på 2000-tallet. Det samme gjelder for det klassiske opptakstallet. Det er bare for jazz-rytmisk at man ser en annen tendens, nemlig en økning på 123 prosent fra 1996 til 2009, eller sagt på en annen måte: en økning fra 15 prosent av det totale antall studenter på 1990tallet til 37 prosent i 2009 .

Dette står allikevel i kontrast til den tendensen man finner hvis man sammenligner hvor mange som blir studenter innenfor hver enkelt av de to sjangergruppene. I 2009 var forskjellen 18 prosentpoeng i favør av klassisk når det gjaldt hvor stor andel av frammøtte til opptaksprøver som ble studenter. I 2004 og 2006 var denne forskjellen på henholdsvis 13 og 14 prosentpoeng. Så selv om jazz-rytmisk $\emptyset$ ker sin andel av studentflokken, synker andelen av frammøtte som blir jazz-rytmiske studenter - sammenlignet med klassisk.

Utviklingen over tid viser altså en økning i antall søknader til de utøvende og pedagogiske utdanningene i Norge. De mannlige jazz-rytmiske søkernes andel av søkergruppen $\varnothing$ ker. Det er et frafall fram mot opptaksprøvene på rundt en tredel, en andel som holder seg stabil. Rundt en tredel av dem som gjennomførte opptaksprøvene, fikk studentstatus. Det har vært en $\varnothing$ kning av studenttallet på 2000-tallet, men sammenlignet med 1990-tallet er opptaket lavere. Jazz-rytmisk øker sin andel av studentflokken, men forholdsvis færre kommer inn, sammenlignet med klassisk.

Hvis man ser på den prosentvise andelen på de tre nivåene søkere, opptaksprøver og studiestart, kan man ane konturene av et mønster som lar seg formulere i en tredelsregel:

To tredeler To tredeler En tredel av det nasjonale antall søknader av det nasjonale antall søkere av de frammøtte til opptaksprøvene er søkere.

møter fram til opptaksprøvene.

møter fram til et studium.

Hva kan man bruke dette til? Å få en oversikt over førsteprioritetssøkerne fra alle aktuelle institusjoner vil ikke by på problemer, for den enkelte institusjon eller for overordnede organer som Database for høyere utdanning. Summen av disse tallene er å betrakte som et 


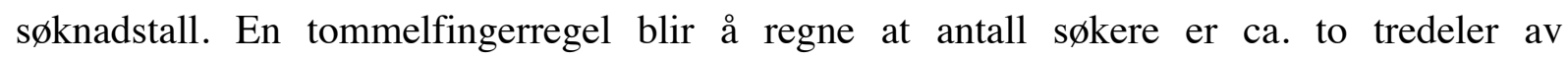
søknadstallet. Og at antall søkere som møter fram til opptaksprøvene, er to tredeler av dette tallet. Antall som får studieplass, er ca. en tredel av dette tallet igjen. Så lenge man ikke har et organ som samordner opptaket innenfor de utøvende musikkutdanningene, gir tredelsregelen en mulighet til på nasjonalt nivå å beregne størrelsen på søkergruppen gjennom de ulike stadiene av søknadsprosessen, noe som tidligere ikke har vært mulig uten å samle inn data på individnivå. Tredelsregelen er derimot ikke egnet på institusjonelt nivå; her er variasjonene for store.

\section{Sammenfatning av funnene}

Hovedfunnene, slik de er beskrevet i denne artikkelen, er følgende: Det er flere jazz-rytmiske enn klassiske søkere til konservatoriesektoren i Norge i dag, hvis vi ser på antall frammøtte til opptaksprøver i 2009. Samtidig går andelen av de jazz-rytmiske søkerne som får studieplass ned, mens de klassiske søkernes sjanse for studieplass $\emptyset$ ker. Det er altså et $\emptyset$ kende misforhold innenfor den jazz-rytmiske søkergruppen mellom etterspørsel og tilbud når det gjelder studieplasser. Jazz-rytmiske søkere fremstiller seg til opptaksprøver ved flere institusjoner i større grad enn klassiske søkere og får uttelling for dette; jo flere opptaksprøver en søker gjennomfører, jo større er sjansen til en studieplass.

Søkningen til rene utøvende studieforløp var i 2009 ca. åtte ganger høyere enn søkningen til pedagogiske studieforløp. Dette forholdet holder seg stabilt over tid. Man finner den samme fordelingen ved studiestart. Når det gjelder den sjangermessige fordelingen, er det en tendens til at andelen jazz-rytmiske studenter på pedagogiske studieforløp $\varnothing \mathrm{ker}$, mens andelen klassiske synker.

Mennene $\varnothing$ ker sin andel av studentgruppen. I 2009 var det mer enn 50 prosent flere menn enn kvinner blant førsteårsstudentene på utøvende og pedagogiske studieforløp. En del av denne $\varnothing$ kningen tilskrives den store $\varnothing$ kningen av andelen menn som søker sang, særlig er $\varnothing$ kningen stor på klassisk sang, men økningen er også tydelig på jazz-rytmisk sang.

Nesten en firedel av årskullet i studieåret 2009/2010 studerte klassisk sang eller jazzrytmisk sang. På grunn av søkermengden er disse to instrumentene vanskelige å komme inn på, med jazz-rytmisk sang som det desidert vanskeligste instrumentet. Generelt er det størst misforhold mellom tilbud og etterspørsel av studieplasser når det gjelder hele den jazzrytmiske instrumentgruppen. 


\section{Noen aspekter ved utviklingen de siste årene}

\section{Er det flere jazz-rytmiske enn klassiske søkere i Norge i dag?}

Er det i Norge i dag flere søkere til de jazz-rytmiske musikkutdanningene enn til de klassiske? Dette var artikkelens innledende og retoriske spørsmål. Det som kan leses ut av tabellene på dette punktet, er at mens klassisk både i 2004 og 2006 lå over jazz-rytmisk, fra fire til åtte prosentpoeng høyere, både når det gjaldt antall søkere og frammøtte til opptaksprøvene, så er situasjonen for 2009 at klassisk ligger likt på antall søkere, men under når det kommer til frammøtte til opptaksprøvene. Jazz-rytmisk har altså styrket sin posisjon i forhold til klassisk på de viktige variablene søkere og frammøtte til opptaksprøver. I 2004 kunne man si at riktignok var det rytmiske tallet på sфknader høyere enn det klassiske tallet, men det var flere klassiske søkere, og de møtte i tillegg fram til opptaksprøvene i større antall, noe som er et viktig poeng. Derfor var svaret på spørsmålet ovenfor, i 2004: "Nei, det er de klassiske søkerne som møter fram i størst antall til opptaksprøvene.” I 2009 var den jazz-rytmiske gruppen større på søknader, den hadde kommet opp på siden av klassisk når det gjaldt søkere, og den var større også når det gjaldt frammøtte til opptaksprøvene. Både i 2004 og i 2006 lå jazz-rytmisk åtte prosentpoeng lavere enn klassisk på opptaksprøvene, i 2009 lå de to prosentpoeng høyere. Så i 2009 hadde jazz-rytmisk hegemoniet også når det gjaldt antall reelle søkere. Svaret på spørsmålet ovenfor var da, i 2009: "Ja, det er de jazz-rytmiske søkerne som møter fram i størst antall til opptaksprøvene."

Det store bildet preges av at jazz-rytmisk i 2009 lå fra ett til fem prosentpoeng over sine egne verdier for 2004, mens klassisk lå fra ett til fem prosentpoeng under sine verdier både fra 2004 og 2006. Selv om forskjellene er små, er det en jevn tendens til at jazz-rytmisk over tid har styrket sin stilling gjennom de fire fasene i opptaksprosessen. Om det er riktig å si at dette har skjedd på bekostning av klassisk, vet jeg ikke. Kanskje er sammenlignet med klassisk et mer dekkende utrykk; jeg kjenner ikke til om det er et nasjonalt trekk at institusjonene bevisst senker inntaket på klassiske studieretninger.

\section{Hvordan er utviklingen når det gjelder søkningen til pedagogiske studieforløp?}

Når det gjelder søkernes ønske om en pedagogisk-utøvende kontra en ren utøvende profil på utdanningen, viser søkertallene for 2009 følgende: Av 907 søkere er det 802 som $\emptyset$ nsker utøvende (88 prosent) og 105 som $\emptyset$ nsker pedagogisk profil (12 prosent). Det er altså nesten åtte ganger så mange søkere til utøvende studier som til pedagogiske. De 105 som $\emptyset$ nsker pedagogisk profil, fordeler seg ganske likt på kvinner og menn (53:47 prosent). Fordelingen på sjanger derimot, viser større forskjeller; de jazz-rytmiske søkerne utgjør hele 66 prosent av 
de 105 søkerne som ønsket pedagogisk profil, de klassiske utgjorde følgelig 34 prosent. Det er altså betydelig flere jazz-rytmiske som søker pedagogisk komponent i utdanningen enn klassiske, og flere klassiske som søker utøvende enn jazz-rytmiske søkere. Åtte prosent av den klassiske søkermassen har pedagogikk som førsteprioritet, mens 15 prosent (nesten dobbelt så mange prosentpoeng) av den jazz-rytmiske søkermassen har pedagogikk på førsteplass. Dette funnet må sies å være overraskende. Jazz-rytmiske studenter har ifølge andre undersøkelser en sterkere utøvende enn pedagogisk identitet (Brändström et al. 1995:154, Tønsberg 2000:88). Dersom de allikevel valgte pedagogisk komponent i utdanningen, var det "med en sterkere fornuftsmessig enn motivasjonsmessig begrunnelse" (Tønsberg 2000:93). Det kan hende at forholdene på arbeidsmarkedet også for jazz-rytmiske musikere etter hvert tilsier at pedagogiske kvalifikasjoner kan komme godt med, som en sikring mot ledighet, og som noe som kan gi flere ben å stå på.

I tabell 6 nedenfor finnes verdier for de tre årene 2004, 2006 og 2009 for utdanningsprofil; om studentene går på et rent utøvende eller et pedagogisk-utøvende studieforløp.

\begin{tabular}{|l|c|c|c|}
\hline & $\mathbf{2 0 0 4}$ & $\mathbf{2 0 0 6}$ & $\mathbf{2 0 0 9}$ \\
\hline Studenter - antall møtt til studiestart & 171 & 175 & 188 \\
\hline Profil & 142 & 127 & 168 \\
& 29 & 48 & 20 \\
\hline
\end{tabular}

Tabell 6 Det nasjonale antall møtt til studiestart for årene 2004, 2006 og 2009, fordelt på pedagogiske og utøvende studieforløp. Absolutte tall.

De 188 nye studentene høsten 2009 fordeler seg med 20 på pedagogisk utdanning og 168 på utøvende. Det er mer enn åtte ganger så mange utøvende studenter som pedagogiske på førsteårskullet 2009-2010, hvilket sammenfaller med fordelingen på søkernivå, der det var nesten åtte ganger så mange søkere til utøvende som til pedagogisk utdanning. Blant de 20 pedagogikkstudentene fordeler kjønnene seg helt likt, med ti kvinner og ti menn; dette er ganske likt med fordelingen på søkernivå (56 kvinnelige søkere til pedagogisk utdanning, 49 mannlige). Sjangermessig er det imidlertid store forskjeller; bare syv prosent av de klassiske førsteårsstudentene går på et pedagogisk studieforløp, mot 17 prosent av de jazz-rytmiske.

Forholdet mellom de to studieretningene holder seg ganske jevnt også over tid, det er mange ganger flere studenter på utøvende enn på pedagogiske studieforløp. Det svinger imidlertid en del, noe som også er tilfellet når det gjelder forholdet mellom den jazz-rytmiske og den klassiske studentgruppen på de pedagogiske studieforløpene. I 2004 og 2006 er det helt jevnt mellom disse to gruppene, i 2009 er det 50 prosent flere jazz-rytmiske 
førsteårsstudenter enn klassiske på et pedagogisk løp. Det er altså, til tross for små og svingende tall, en tendens til en økning av den jazz-rytmiske andelen av førsteårsstudenter på et pedagogisk studieforløp.

Boysenrapporten (KUF 1999) anbefaler nasjonal fagprofilering og arbeidsdeling når det gjelder balansen mellom ulike studier. Rapporten hevder at det har skjedd en studenttallsforskyvning fra pedagogiske til rent utøvende ved enkelte av konservatoriene på 1990-tallet, en utvikling som burde reverseres. Rapporten hevder videre:

Etter utvalgets oppfatning må pedagogiske studier være den viktigste studieretning ved alle konservatorier, uansett sjanger. Det er derfor viktig at institusjonene opprettholder en streng styring av opptaket til de ulike studieretninger. Søkerinteressen vil alltid være større for rent utøvende utdanninger, men institusjonene har et ansvar for å ta hensyn til både behovene i arbeidsmarkedet og de utdannede kandidatenes arbeidsmuligheter etter endt utdanning når studieplassene skal disponeres (pkt. 8.4).

Nå er det ikke mulig å sammenligne tallene i Boysenrapporten direkte med tallene i min egen undersøkelse, men for opptaksåret 1999 var andelen førsteårsstudenter på pedagogiske studieforløp, ved de tre institusjonene som i 2009 tilbød pedagogikk fra første år, 20 prosent av det totale studenttallet. Ti år senere har andelen sunket til 11 prosent. På denne tiden har altså utviklingen gått fra fem ganger så mange til åtte ganger så mange utøvere som pedagoger på første år av grunnutdanningene. Studenttallsforskyvningen er ikke blitt reversert, den har blitt enda skjevere. Boysenrapportens anbefaling om at institusjonene "opprettholder en streng styring av opptaket" har altså ikke blitt fulgt, eller institusjonene har ikke villet nøde studentene med førsteprioritet på utøvende til å begynne på et pedagogisk studieforløp.

Som nevnt baserer konklusjonene vedrørende en $\emptyset$ kende pedagogisk-utøvende skjevhet seg bare på tre institusjoner. De andre tre institusjonene, som tilbyr praktiskpedagogisk utdanning senere i studieforløpet, omfattes ikke av min undersøkelse av søkningen til pedagogiske studieforløp. Det kan meget vel være slik at antall studenter som tar en ettårig praktisk-pedagogisk utdanning etter to-tre år med utøvende studier er både høyt og stabilt, men det kan det ikke sies noe om i denne artikkelen. Slik jeg kjenner konservatoriesektoren, er det imidlertid grunn til å tro at etter noen år som utøvende studenter er det mange som, etter å ha foretatt realitetsvurderinger av sine egne sjanser på arbeidsmarkedet, har funnet ut at det er nødvendig å sikre seg mot ledighet, at det er greit å ha flere ben å stå på, og at pedagogiske kvalifikasjoner derfor kan komme godt med. Når disse velger å skaffe seg en pedagogisk komponent i utdanningen, er det ikke bare med en 
fornuftsmessig, men også en motivasjonsmessig begrunnelse. Etter et slikt resonnement burde et mulig tiltak for å $\emptyset$ ke andelen av pedagogiske studenter være å opprette ettårige praktiskpedagogiske utdanninger også ved de institusjonene som i dag tilbyr tre- eller fireårige faglærerutdanninger. Alternativt burde man vurdere å avvikle tilbudet om faglærerutdanning fra første år, for å nyte godt av utøvende studenters antatt фkende selverkjennelse når det gjelder mulighetene på arbeidsmarkedet, og den derav følgende høyere motivasjon for pedagogisk utdanning.

\section{Lønner det seg å fremstille seg til flere opptaksprøver?}

Som nevnt flere ganger tidligere, er noe av denne undersøkelsens anliggende å finne ut av hvilke utslag eller konsekvenser det har å søke seg til flere institusjoner og å møte fram til flere opptaksprøver. En indikasjon finner vi i tabell 7 nedenfor, der den prosentvise sjansen for å få studieplass sett i forhold til antall studiesteder som er oppsøkt, er beregnet.

\begin{tabular}{|c|c|c|c|}
\hline $\begin{array}{l}\text { Antall opps } \varnothing \mathrm{kte} \\
\text { institusjoner }\end{array}$ & $\begin{array}{l}\text { Antall frammøtte } \\
\text { til opptaksprøver }\end{array}$ & $\begin{array}{l}\text { Antall som fikk } \\
\text { studieplass }\end{array}$ & $\begin{array}{l}\text { Andel som ble student av antall } \\
\text { frammøtte til opptaksprøver }\end{array}$ \\
\hline 1 & 395 & 94 & $24 \%$ \\
\hline 2 & 155 & 66 & $43 \%$ \\
\hline 3 & 44 & 21 & $48 \%$ \\
\hline 4 & 10 & 5 & $100 \%$ \\
\hline 5 & 2 & 2 & \\
\hline
\end{tabular}

Tabell 7 Den prosentvise sjansen for å bli student sett i forhold til antall institusjoner den enkelte søker oppsøkte i 2009. $\mathrm{N}=606$.

Som tabellen viser, øker sjansen for å få studieplass når antall oppsøkte institusjoner øker; jo flere opptaksprøver man møter fram til og gjennomfører, jo større sjanse for opptak. Under en tredel av det totale antall frammøtte til opptaksprøver fikk studieplass (31 prosent), mens begge de to som møtte opp fem steder, og nær halvparten av dem som møtte til tre eller fire opptaksprøver, kom inn på et studium. Datamaterialet viser dessuten at samtlige av dem som våren 2009 møtte fire eller fem steder, var jazz-rytmiske søkere, noe som også gjaldt nesten to tredeler av dem som møtte tre steder. Nærmere syv av ti søkere som møtte tre eller flere steder, var også menn. De samme tendensene finner man for 2004 og 2006. Det er typisk at det er de mannlige jazz-rytmiske søkerne som i størst grad bruker ressurser på å reise Norge rundt på opptaksprøveturné; investeringer som gir rask og god avkastning. Hvorfor de handler som de gjør, kan bare videre undersøkelser gi svar på, men uansett begrunnelser: Mange søkere nøyer seg ikke med å "komme i betraktning for restplass også der du ikke har 
prøvespilt” http://hoyere-musikkutdanning.no [18.06.2012], men tar selv regien og posisjonerer seg i forhold til den sektoren de søker seg til.

\section{Hvorfor øker andelen av menn i de utøvende utdanningene?}

Den kjønnsmessige forskjellen i utviklingen over tid er et slående trekk. For det første er det et så likt antall kvinner og menn på alle de fire nivåene i 2004 at å snakke om en forskjell dette året har ingen mening. Men så øker forskjellen fra år til år mellom i hvilken grad kjønnene er representert på de ulike nivåene og i de ulike fasene, slik at det er relevant å kalle det en markant kjønnsmessig forskjell i utviklingen av søkningen til de utøvende musikkutdanningene i Norge de siste årene. Etter at antall søkere sank i 2006, både for kvinner og menn, hadde antall mannlige søkere i 2009 steget med 37 prosent sammenlignet med antall mannlige søkere i 2004, mens det tilsvarende tallet for kvinner var en nedgang på 16 prosent. Og mens det var seks færre menn enn kvinner som møtte til opptaksprøvene i 2004, var det en overvekt på 84 menn ved opptaksprøvene i 2009, der altså de mannlige søkerne utgjorde 57 prosent og de kvinnelige 43 prosent av de frammøtte. Ved studiestart samme høst ble det en enda større overvekt av menn: 61 prosent av førsteårsstudentene var menn, kvinnene utgjorde 39 prosent.

En del av økningen av den mannlige studentmassen høsten 2009 kan tilskrives det store inntaket på klassisk og jazz-rytmisk sang. Av figur 5 ovenfor går det fram at hele 43 av førsteårsstudentene i studieåret 2009-2010 studerte disse to instrumentene; det utgjør nesten en firedel av hele årskullet (23 prosent). Dette har sammenheng med at andelen menn blant søkerne til klassisk sang steg fra 15 prosent i 2004 til 25 prosent i 2009, altså en økning på ti prosentpoeng i dette tidsrommet. Men hva med jazz-rytmisk sang? Også der kan det spores en nesten like stor $\varnothing \mathrm{kning}$ blant den mannlige delen av søkerne, fra 14 prosent i 2004 til 21 prosent i 2009. Hva kan årsaken være til denne endringen i interessen hos unge gutter for å synge, både innenfor klassiske og jazz-rytmiske sjangere? Internasjonale strømninger og norske fjernsynsproduksjoner som Norske talenter, Kjempesjansen, Idol og lignende, der ofte mannlige sangere har gått av med seieren, kan ha gitt impulser i en slik retning.

Men hva med nedgangen i antall og andel kvinner innenfor sektoren? En forklaring kan være at store, samfunnsnyttige og trygge profesjonsutdanninger som sykepleie og lærer tiltrekker kvinner i den grad at dette kan påvirke søkningen til de mer usikre kunstnerutdanningene. 


\section{På hvilke instrumenter har man størst sjanse for å få studieplass?}

De store vinnerne etter analysen av instrumentfordelingen ved studiestart høsten 2009 var klassisk gitar og strykeinstrumenter, med en prosentvis sjanse for studieplass på 50 eller høyere. Tabell 8 nedenfor gir en oversikt også over de to andre årene over hvor mange prosent av de frammøtte til opptaksprøver som ble studenter samme år, fordelt på instrumentgrupper.

\begin{tabular}{|l|c|c|c|}
\hline $\begin{array}{l}\text { Instrumentgrupper ved studiestart - } \\
\text { prosentandel av møtt til opptaksprøver }\end{array}$ & $\mathbf{2 0 0 4}$ & $\mathbf{2 0 0 6}$ & $\mathbf{2 0 0 9}$ \\
\hline Gitar & $75 \%$ & $46 \%$ & $53 \%$ \\
Strykeinstrumenter & $38 \%$ & $35 \%$ & $50 \%$ \\
Klaver & $51 \%$ & $59 \%$ & $39 \%$ \\
Treblåseinstrumenter & $39 \%$ & $41 \%$ & $38 \%$ \\
Messinginstrumenter & $31 \%$ & $44 \%$ & $36 \%$ \\
Klassisk sang & $25 \%$ & $23 \%$ & $31 \%$ \\
Jazz-rytmiske instrumenter (ekskl. sang) & $23 \%$ & $28 \%$ & $24 \%$ \\
Jazz-rytmisk sang & $15 \%$ & $16 \%$ & $17 \%$ \\
\hline
\end{tabular}

Tabell 8 Andelen møtt til studiestart i 2004, 2006 og 2009, sett i forhold til antall frammøtte til opptaksprøver, fordelt på instrumentgrupper og sortert etter verdiene for 2009. Prosentuerte tall. Marginale instrumenter som akkordeon, harpe og klassisk slagverk er ikke tatt med.

Verdiene for de store instrumentgruppene i tabellen ovenfor uttrykker den sjansen som en søker innenfor den enkelte instrumentgruppe hadde for å få en studieplass henholdsvis i 2004, 2006 og 2009. Prosentueringene viser også de store forskjellene som råder mellom tradisjonelle, klassiske instrumenter som gitar og klaver på den ene siden og de jazz-rytmiske instrumentene på den andre siden, når det gjelder søkernes sjanse på en studieplass. At det kan spores en nedgang fra 2004 til 2009 for akkurat gitar og klaver, kan skyldes en tilfeldighet. Når gitar troner gjennomsnittlig høyest på sjansestatistikken, er dette et uttrykk for lav søkning kombinert med ledig kapasitet blant gitarlærere ved institusjonene. Tilsvarende er tilfelle også med strykeinstrumentene når det gjelder lave søkertall, men her kan det finnes en etterspørsel både fra institusjonene og ellers i samfunnet, og etter hvert også fra den medieformidlede underholdningsindustrien. Mer midt på treet ligger de store instrumentgruppene treblås, messing og stryk, på mellom 35 og 50 prosent sjanse for opptak, med strykeinstrumentene som den gruppen som har hatt mest økning de siste årene. At klassisk sang ligger lavere enn de nevnte instrumentgruppene i relativ sjanse for opptak, skyldes de store massene av søkere på dette instrumentet. Her må imidlertid bemerkes den store forrykkingen av kjønnsbalansen de senere årene, der altså mennenes andel av de klassiske sangsøkerne har økt nokså jevnt. 
Som det desidert vanskeligste instrumentet å komme inn på, av instrumentgrupper av en viss størrelse, finner vi jazz-rytmisk sang. Som på klassisk sang må også her det store søkertallet ta skylden for det prosentmessig lave opptaket, men i tillegg spiller det nok en rolle at tre av de seks institusjonene ikke etablerte jazz-rytmiske utdanninger før ut på 2000-tallet (den siste i 2004), og disse har til sammen et relativt lavt antall studieplasser foreløpig (Tønsberg 2007) sammenlignet med antall klassiske studieplasser. Også her må bemerkes $\varnothing$ kningen i andelen menn som søker rytmisk sang fra 2004 til 2009; ikke like stor som for klassisk sang, men den er jevnt økende. Det som skiller jazz-rytmisk sang fra de фvrige instrumenter og instrumentgrupper, er den lille, men allikevel jevnt stigende utviklingstendensen i årene 2004-2009. Her blir det altså gradvis bedre sjanser for å få studieplass. At de $\emptyset$ vrige jazz-rytmiske instrumentene ligger samlet nest nederst i "sjanselista", henger selvsagt sammen med den samme sene etableringen som nevnt ovenfor, men antall søkere her er ikke så formidabelt som til jazz-rytmisk sang, så utslaget blir ikke like stort.

\section{Avslutning}

\section{Samordna opptak for utøvende musikkutdanning?}

Undersøkelsen som denne artikkelen bygger på, hadde som utgangspunkt en antakelse om at antall søkere til de utøvende musikkutdanningene i Norge var lavere enn de offisielle tallene i DBH-basen skulle tilsi. Analysen har vist at en stor andel av søkerne går igjen i søkerlistene ved musikkutdanningsinstitusjonene. Og denne gruppen av "Tordenskjolds soldater", selv etter å ha korrigert for effektene av dem, har vist seg å være dominert av mannlige jazzrytmiske søkere, som benytter seg av et ikke-samordnet opptaksregime til å reise på opptaksprøveturné og fremstille seg til opptaksprøver Norge rundt; en praksis som gir uttelling i form av $\varnothing \mathrm{kt}$ sjanse for studieplass.

Burde det på denne bakgrunn etableres et Samordna opptak for utфvende musikkutdanning (SOUM) underlagt Nasjonalt fagråd for utøvende musikkutdanning og musikkvitenskap? At svaret på et slikt spørsmål er ja, kan virke innlysende, fordi noen fordeler er åpenbare, slik begrunnelsene for etablering av Samordna opptak på 1990-tallet også var. For det første ville sektoren kun behøve å forholde seg til et netto og oversiktlig antall søkere, ikke også et brutto og uoversiktlig antall søknader, som i dag. Dernest ville man oppnå en ressursbesparelse ved at parallellsøkningen og dermed den mangedobbelte saksbehandlingen fram mot opptaksprøvene ville opphøre. For det tredje ville man etter 
kvalifiseringen ved opptaksprøvene unngå alle brevene fra hver enkelt institusjon med tilbud om studieplass; brev som én og samme person i dag mottar flere av, og som skaper mye venting og usikkerhet om rekrutteringen utover våren og sommeren. For det fjerde ville man unngå den situasjonen man har i dag: en tilfeldig eller kanskje også usosial tildeling av studieplasser, der de med mest ressurser møter fram til flest opptaksprøver og har størst sjanse til studieplass.

Felles for disse begrunnelsene er at de først og fremst er fordeler for institusjonene selv. For søkerne kunne man tenke at det ville være en fordel å slippe å skrive opptil seks søknader. Med et "Samordna opptak for utøvende musikkutdanning" ville det være nok med én søknad til en sentral instans, hvor saksbehandlingen av studiekompetanse og andre formaliteter kunne skje av et kompetent byråkrati. En slik sterkere samordning ble foreslått høsten 2009 av daværende Nasjonalt fagråd i utøvende musikkutdanninger og musikkvitenskap: "Opptaksprøver - bør de koordineres eller kan det være aktuelt å sperre for at søkerne kan sette opp flere steder og i praksis dra på prøvespillturné.” (Fra referat fra møte 27.10.2009, sak 11/2009). Etter min mening bør fordelingen av søkerne på de oms økte studiestedene kunne skje mest mulig etter søkernes prioriteringer, slik at søkerne kunne fremstille seg til opptaksprøver der de selv ville og i det antallet de selv ville. Dette siste kan virke som en underlig påstand, etter å ha "avslørt" omfanget av denne praksisen. Men for det første er det slik at en søker som er blitt funnet kvalifisert ett sted, men ikke får studieplass, allikevel må prøvespille på nytt ved en annen institusjon som måtte ha plass for denne søkeren; dette på grunn av forskjellighet i vurderingskriterier, profilering, tradisjoner og skoler og at "kjemien" må stemme mellom lærer og student.

For det andre er det ikke uten betydning for den enkelte søker hvilken institusjon han eller hun blir tilbudt opptak til. Tvert imot søkes det bevisst til spesifikke studiesteder hvor man finner de rette møteplassene studentene imellom og mellom studenter og lærere, hvor de sistnevnte ses på som portåpnerne, for eksempel ut til den medieformidlede underholdningsindustrien, og hvor de innenfor sitt eget sjangerområde kan få utvikle seg videre fra et allerede høyt ferdighetsnivå. Skulle "forbudet" i fellesbrosjyren mot å søke flere enn to eller tre institusjoner bli håndhevet strengt, ville ulempene for søkerne kunne overstige fordelene, med de eventuelt negative konsekvensene dette måtte få for rekrutteringen til sektoren. Et SOUM måtte derfor ikke bringe til opphør praksisen med opptaksprøveturné Norge rundt, men all administrasjon før og etter opptaksprøvene ville kunne samles ett sted og forenkles betydelig, sett i forhold til dagens praksis. 


\section{Tilbud og etterspørsel og musikkutdanningsinstitusjonenes samfunnsoppdrag}

Hvis man tar utgangspunkt i etterspørselen uttrykt ved antall frammøtte til opptaksprøver, og tilbudet uttrykt ved antall ledige studieplasser, fordelt på klassisk og jazz-rytmisk, hvor finner man det største misforholdet? Svaret er på området jazz-rytmiske studieplasser, og tendensen er at misforholdet er stigende. Jazz-rytmisk $\emptyset$ ker riktignok sin andel av studentflokken, men andelen av frammøtte som blir jazz-rytmiske studenter synker, sammenlignet med klassisk. Anbefalinger om en utvikling mot flere studieplasser for jazz-rytmiske studenter står å lese både i rapportene etter de nasjonale musikkutdanningsevalueringene midt på 1990-tallet og i Boysenrapporten fra 1999. Når det per 2012 ennå ikke har kommet i gang styring fra sentralt hold om økning av jazz-rytmiske studieplasser, er det tvilsomt om så vil skje i overskuelig fremtid. Samtlige utøvende musikkutdanninger er nå organisert under et universitet eller en vitenskapelig høgskole, som alle har rett til selv å bestemme studieportefølje og avgjøre studentopptak. Men nettopp derfor kan det også tenkes at institusjonsledere som måtte bli gjort kjent med at det nasjonale antall frammøtte til opptaksprøvene i 2009 var høyere på jazzrytmisk enn på klassisk, vil tenke at fortsatt opprettholdelse av klassiske studieplasser ikke vil være forsvarlig, bedrifts $\varnothing$ konomisk sett.

Til det er å si at det neppe vil være samfunnsøkonomisk fornuftig å opprette enda flere studieplasser for eksempelvis jazz-rytmiske sangere, for å rette opp et misforhold mellom etterspørsel og tilbud; et slikt tiltak kan bidra til å skape et enda større misforhold. Samfunnets behov for formelt utdannede sangere, det være seg innenfor klassiske eller jazz-rytmiske sjangere, er neppe så stort som antall søkere til disse instrumentene. For institusjonene å anlegge et for snevert bedriftsøkonomisk perspektiv på utviklingen er derfor ikke tilstrekkelig. Fortsatt satsning på forskning, utdanning og formidling innenfor den lokale, den regionale, den norske og den nordeuropeiske kulturarven, kan være vel så fornuftig som å la etterspørselen bestemme hva som tilbys av studier. I et slikt perspektiv er en nasjonal overvekt av klassisk-musikalske studieplasser ikke nødvendigvis uttrykk for et misforhold, men for et samsvar med de rollene utdanningsinstitusjonene ifølge Kunnskapsdepartementet skal spille i samfunnet, nemlig som "kulturbærere og kulturformidlere"

\footnotetext{
${ }^{1}$ http://www.regjeringen.no/nb/dep/kd/dep.html?id=591 [28.02.2012]
} 


\section{Referanser}

Brandt, S.S., Aamodt, P.O. og Støren, L.A. (2005). Gjennomgang av NIFU-forskning på området "Studierekruttering og gjennomføring av hфyere utdanning” i perioden 1991-2004. NIFU STEP Arbeidsnotat 2005:7. Oslo: Norsk institutt for studier av forskning og utdanning/Senter for innovasjonsforskning.

Brändström, S. og Wiklund, C. (1995). Två musikpedagogiska fält. En studie om kommunal musikskola och musiklärarutbildning. Umeå: Umeå universitet.

Jacobsen, D.I. (2000). Hvordan gjennomføre unders $\phi$ kelser? Innføring $i$ samfunnsvitenskapelig metode. Kristiansand: Høyskoleforlaget.

Jacobsen, D.I. (2003). Forståelse, beskrivelse og forklaring. Innføring i samfunnsfaglig metode for helse- og sosialfagene. Kristiansand: Høyskoleforlaget.

KUF (1996). Nasjonal evaluering av hфyere utdanning. Fagområde musikk. Sakkyndig rapport 2. Oslo.

KUF (1999). Fra vugge til podium. Utredning om den faglige organiseringen av musikkutdanningen. Oslo.

Lovdata (2001). Lov om behandling av personopplysninger. http://www.lovdata.no/all/nl-20000414-031.html [28.09.2011]

NESH (2006). Forskningsetiske retningslinjer for samfunnsvitenskap, humaniora, juss og teologi. Oslo.

Skjersli, S. (2000). S $\phi k e r e$ til høyere utdanning. Endring i sфkning, tilbud og opptak 19951999. NIFU Skriftserie 2000:8. Oslo: Norsk institutt for studier av forskning og utdanning/Senter for innovasjonsforskning.

Tønsberg, K. (2000). Er det noen kunst å vare rytmisk musiker? En unders $\emptyset$ kelse av yrkeslivet til rytmiske musikere og musikkpedagoger som er utdannet ved musikkonservatoriet ved Høgskolen i Agder. Kristiansand: Universitetet i Agder. Forskningsserien 2000:23.

Tønsberg, K. (2007). Institusjonaliseringen av de rytmiske musikkutdanningene ved Høgskolen $i$ Agder. Avhandling for graden Ph.D. Norges musikkhøgskole. Oslo: NMH-publikasjoner 2007:2. 


\section{Figurer og tabeller}

Figur 1 Den nasjonale søkermassen i Norge i 2009. Fordelingen av jazz-rytmiske og klassiske søkere på antall søkte institusjoner. Absolutte tall. $\mathrm{N}=907$.

Figur 2 Den nasjonale søkermassen i Norge i 2009. Søkerne fordelt på instrument. Kun instrumenter med flere enn 40 søkere er vist. Absolutte tall. $\mathrm{N}=907$.

Figur 3 En oversikt over antall institusjoner jazz-rytmiske og klassiske søkere møtte fram til opptaksprøver ved. Absolutte tall. $\mathrm{N}=606$.

Figur 4 En fremstilling av andelene i 2009 av jazz-rytmiske og klassiske søknader, søkere, møtt til opptaksprøver og møtt til studiestart. Prosentuerte verdier.

Figur 5 Instrumentfordelingen høsten 2009 blant jazz-rytmiske og klassiske førsteårsstudenter. Kun de 15 instrumentene med fem eller flere studenter er tatt med. De øvrige 13 instrumentene, 10 klassiske og 3 jazz-rytmiske, har fra én til fire studenter. Absolutte tall. $\mathrm{N}=188$.

Tabell 1 Det nasjonale antall søknader for årene 2004, 2006 og 2009. Absolutte tall.

Tabell 2 Det nasjonale antall søkere for årene 2004, 2006 og 2009. Absolutte tall.

Tabell 3 Det nasjonale antall frammøtte til opptaksprøver for årene 2004, 2006 og 2009. Absolutte tall.

Tabell 4 Det nasjonale antall møtt til studiestart for årene 2004, 2006 og 2009. Absolutte tall.

Tabell 5 Antall studenter tatt opp på en grunnutdanning, i fem ulike år, fordelt på klassisk og jazz-rytmisk. Absolutte tall.

Tabell 6 Det nasjonale antall møtt til studiestart for årene 2004, 2006 og 2009, fordelt på pedagogiske og utøvende studieforløp. Absolutte tall.

Tabell 7 Den prosentvise sjansen for å bli student sett i forhold til antall institusjoner den enkelte søker oppsøkte i 2009. N = 606 .

Tabell 8 Andelen møtt til studiestart i 2004, 2006 og 2009, sett i forhold til antall frammøtte til opptaksprøver, fordelt på instrumentgrupper og sortert etter verdiene for 2009. Prosentuerte verdier. 